\title{
Inter-industry relatedness and industrial-policy efficiency: Evidence from China's Export Processing Zones
}

Zhao Chen, Sandra Poncet \& Ruixiang Xiong

\section{Highlights}

- We evaluate whether the efficiency of industrial policies depends on the consistency of their focus with the local productive structure.

- We find positive export repercussions from the EPZ policy which are greater for sectors with denser the links with the local productive structure.

- Our results suggest that industrial-policy effectiveness is magnified by pre-existing productive knowledge.

- The export gains from the establishment of an EPZ are higher for a sector at the 90th percentile relative to a sector at the 10th percentile of the distribution of density, by a factor 1.24 for the non-targeted sectors.

- This factor is reinforced for sectors that are selected to benefit from the EPZ policy and rises to 1.27 for these targeted sectors. 


\section{Abstract}

In this paper, we evaluate whether the efficiency of industrial policies depends on the consistency of their focus with the local productive structure. We use sector-level data from Chinese manufacturing surveys over the 1998-2007 period to show that the efficiency of the export-promoting policies implemented in Export Processing Zones depends on whether they target activities for which the necessary capabilities and resources are available. We find export benefits from the EPZ policy which are greater for sectors with denser links with the local productive structure. Our results suggest that industrial-policy effectiveness is magnified by pre-existing productive knowledge.

I Keywords

Export Processing Zones, Industrial Policy, Export Promotion Effectiveness, China.

I JEL

F13, F14, O25, R11.

Working Paper

CEPII (Centre d'Etudes Prospectives et d'Informations Internationales) is a French institute dedicated to producing independent, policyoriented economic research helpful to understand the international economic environment and challenges in the areas of trade policy, competitiveness, macroeconomics, international finance and growth.

CEPII Working Paper
Contributing to research in international
economics
C CEPII, PARIS, 2016
All rights reserved. Opinions expressed
in this publication are those of the
author(s) alone.

Editorial Director: Sébastien Jean

Production:

Laure Boivin

No ISSN: 1293-2574
CEPII

113, rue de Grenelle

75007 Paris

+33153685500

www.cepii.fr Press contact: presse@cepii.fr

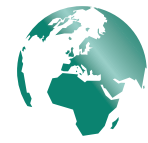




\title{
Inter-industry relatedness and industrial-policy efficiency: Evidence from China's Export Processing Zones
}

\author{
Zhao Chen*, Sandra Poncet ${ }^{\dagger}$ and Ruixiang Xiong ${ }^{\ddagger}$
}

\section{Introduction}

China is probably one of the best-known examples of the use of spatially-targeted programs. Starting in 1979, the Chinese government established a multitude of Special Economic Zones as jumping-off points for its internationalization strategy. The country is a major player in the worldwide proliferation of export processing zones (EPZs) ${ }^{1}$ and opened 57 between 2000 and 2005 across its vast and heterogeneous territory. Tax and customs duty incentives and various types of preferential treatment regarding land and property rights were granted in order to promote the specific sectors that were seen by the central and local authorities as being more desirable (Wang and Wei, 2010). A growing literature has however warned against the inconsistency of industrial policy with the local productive structure (Lin, 2012, Cai et al., 2011). The production of goods requires capabilities and products that vary considerably in their knowledge requirements (Hausmann and Hidalgo, 2011). As the cities in which the EPZs are established may differ in terms of their existing productive knowledge, any failure to match the promoted products to the necessary capabilities and resources may limit the capacity of the EPZs to effectively promote exports.

\footnotetext{
* China Centre for Economic Studies, Fudan University, email: zhaochen@fudan.edu.cn.

$\dagger$ Paris School of Economics (University of Paris 1) and CEPII, email: sandra.poncet@univ-paris1.fr.

$\ddagger$ Corresponding author: Business School of Xiangtan University, email: xrx_1@163.com.

${ }^{1}$ Approximately 3,000 zones (especially export processing zones) currently exist in 135 countries (Akinci and Crittle, 2008).
} 
Despite the high expectations regarding export creation by Chinese EPZs, there is little empirical evidence on their effectiveness or the repercussions of any potential inconsistency between sectoral targeting and the local productive structure. This paper investigates the effect of the establishment of Export Processing Zones on Chinese exports. To identify the causal export effect of this industrial policy, we use sector-level data and exploit information on the targeted sectors in each zone. Our identification exploits variations in the expected impact of the EPZ policy by sector to isolate the direct causal effect on export promotion. We furthermore investigate whether the effect depends on the local availability of the necessary capabilities and resources.

Our paper contributes to the existing literature in two ways. First, we add to the recent literature on the effectiveness of preferential regional policy programs in China (Wang, 2013; Schminke and Van Biesebroeck, 2013; Adler et al., 2013; Cheng, 2014). ${ }^{2}$ Some of this work has considered EPZs in their list of economic zones (Wang, 2013; Adler et al., 2013, Cheng, 2014) but focus on the repercussions on local GDP growth. This work exploits the variation in the establishment of special zones across time and space, typically using locations without any special policy treatment as the control group. Since EPZ location is likely not exogenous to economic activity, this raises concerns about the comparability of the zones with and without the policy, and hence the reliability of the resulting estimates. The Chinese government may have tried to "pick winners" notably in terms of export potential when it selected the 57 zones which would host an EPZ. This would manifest itself as a positive association between EPZ establishment and exports.

The analysis proposed here is at the location-sector level. We exploit information on the

\footnotetext{
${ }^{2}$ Schminke and Van Biesebroeck (2013) look at the export-promotion effects of Economic and Technological Development Zones (ETDZs) and Science and Technology Industrial Parks (STIPs).
} 
sectors that are treated as priorities by the local government in their efforts to develop export-processing activities. ${ }^{3}$ We test whether the sectors explicitly targeted by local authorities export more in the post-EPZ establishment period, relative to the pre-EPZ period and non-targeted sectors. This difference-in-differences analysis helps to counter the endogeneity issue, which has traditionally hampered the impact evaluation of industrial policies at the macro level (Harding and Javorcik, 2011). We include time-varying location fixed effects to control for local endowments and other time-variant unobservables that could influence export performance in a particular location-sector combination. Our preferred empirical specification includes city-year, sector-year and city-sector fixed effects. In other words, our analysis focuses on within city-sector variation in performance, and tests whether the sectors explicitly targeted by local governments in their efforts to promote processing export more in the post-targeting period, relative to the pre-targeting period and the non-targeted sectors. We focus on export growth to measure the efficiency of EPZs, as the preferential policies in these zones were clearly aimed at helping firms to become more international. Our approach is thus similar to that in Schminke and Van Biesebroeck (2013), who use firm-level customs data to assess the effect of technological development zones. Their evaluation is based on the comparison of new firms locating in these zones to entrants locating outside these areas. We here rather exploit sector-level data meaning that we can observe export performance both before and after the EPZ policy, which is key to our identification strategy.

Second, we investigate whether the efficiency of EPZs depends on the consistency of their focus with local comparative advantage. Our work follows recent efforts to measure

\footnotetext{
${ }^{3}$ Our setting is similar to the recent strand of the FDI literature which exploits the within-country sectoral variation in the targeting practices in order to identify the repercussions of FDI promotion policies (Harding and Javorcik, 2011; Harding and Javorcik, 2012).
} 
the gains from matching between an activity and the local productive structure. We expect positive effects from the local availability of the necessary capabilities and resources (Crozet and Trionfetti, 2013; Lin, 2012, Hausmann and Klinger, 2007; Hidalgo et al., 2007). ${ }^{4}$ Using export data from Chinese exporters, Poncet and Starosta de Waldemar (2013) find that products that are more similar to the local export basket have an export advantage in firm export bundles. This finding is consistent with economies of scale and scope, and knowledge spillovers from product-level relatedness. We here depart from this literature on the direct gains from the consistency of activities with the local productive structure as we consider the relationship between this consistency and industrial policy. Our study relates to the growing literature that cautions against one-size-fits-all policy that disregards local circumstances (Kali et al., 2013; Lin, 2012; Cai et al., 2011). Cai et al. (2011) is our most closely-related predecessor as it asks whether the effect of tariff and tax interventions on firm-level TFP in China depends on local initial conditions (R\&D, skill and export intensities). Our key indicator reflects the density of the links between the targeted sectors and the local product space. It is constructed using international information on the intrinsic relatedness of products, which does not suffer from endogeneity. ${ }^{5}$ This particularity allows us to determine the causal effect of the EPZ policy on exports, even if the selection of EPZs and targeted sectors was not exogenous to economic activity. As industries vary in terms of their intrinsic density of links to the local productive structure, we expect preferential EPZ policies to have a greater effect on activities when there is more pre-existing productive knowledge. We thus filter out the impact of the EPZ policy

\footnotetext{
${ }^{4}$ Crozet and Trionfetti (2013) show that countries' comparative advantages matter for the explanation of relative performances within industries.

${ }^{5}$ The calculations appeal to the Product Space representation developed by Hausmann and Klinger (2007) and Hidalgo et al. (2007). The Product Space is a network that formalizes the notion of relatedness between products traded in the global economy. We use the Hidalgo et al. (2007) indicator of proximity based on world co-exporting probabilities, which are hence not related to the particularities of Chinese locations.
} 
using the density index, which captures the intrinsic predisposition to benefit from exportpromoting policies. This strategy is conceptually similar to a triple-difference estimation. We compare i) locations before and after the introduction of the EPZ policy (the first difference), ii) targeted vs. non-targeted sectors (the second difference), and iii) sectors with higher vs. lower density (the third difference).

Using sector-level data from Chinese manufacturing surveys over the 1998-2007 period, we show that the efficiency of the export-promoting policies implemented in Export Processing Zones depends on how sectoral activities relate to local comparative advantage. Our main findings are of a relative rise in sector-level exports following the EPZ policy that is larger when the sectors targeted have denser links to the local productive structure. Our results suggest that the effectiveness of industrial policy is magnified by pre-existing productive knowledge. This is in line with Cai et al.'s (2011) results that tariff and tax interventions in China were most successful when targeted at sectors where there was either comparative advantage or latent comparative advantage.

We check that our message remains unchanged in a series of sensitivity analyses, including looking for different pre-treatment time trends, excluding certain particular geographic zones or sectors, and including proxies for differences between the treated and non-treated sectors.

The remainder of the paper is structured as follows. The next section discusses the EPZ policy, and Section 3 then describes the data and our variable construction. Section 4 presents our empirical specification and discusses the issues of endogeneity and causality. Section 5 discusses the results, followed by robustness checks and alternative indicators. Finally, Section 6 concludes. 


\section{Export Processing Zones}

Export processing zones were developed in response to China's accession to the WTO in 2001, which required the tighter regulation of processing trade. The Chinese decided to focus the development of this trade within these zones. As described in Feenstra et al. (2013), export processing activities within EPZs enjoy additional advantages compared to those outside the zones. Whatever the location, processing activity benefits from dutyfree imports, and hence does not have to temporarily post bonds for the tariffs on these imports until they are processed into exports. In EPZs, firms also pay no taxes on utilities and their activities are free of value-added and excise taxes. The objective is to grant zero export taxation on exports in order to eliminate double taxation before the exported products reach the consumers in the importing country. In addition, firms in EPZs benefit from advantageous land prices, possible direct subsidies and a more efficient business environment: for example, customs typically provide a 24-hour service within these zones.

A total of 57 export-processing zones were established in China between 2000 and 2005. A first group of 15 export-processing zones were initially approved in April 2000 by the State Council. Subsequently, 3, 8, 13, and 18 EPZs were approved in 2001, 2002, 2003, and 2005, respectively. Many provinces (23 out of 31 ) include such zones, with the largest number being found in Jiangsu province (13 in 2005).

EPZs have a sectoral focus. Some specific activities are officially listed as being priorities in the EPZs' attempts to develop export-processing activities. Firms operating in the targeted sectors of an EPZ are hence more likely to be accepted into the EPZ and to establish themselves there. While electronics is a priority sector in most of the established 
EPZs, the exact list of priority sectors varies across zones. The fact that some sectors are listed as being priorities in all EPZs is a first indication that targeting does not systematically relate to comparative advantages, hence to intrinsic export performance potentials. This is in line with the general ideal that targeting is a policy tool based on many factors (Harding and Javorcik, 2012). We expect that the choice of priority sectors in the official EPZ documents is not mainly directly driven by superior local export prospects from that sector. Nevertheless, we test whether this is true and show that our assumption is reasonable. To verify the validity of this identification assumption, we conduct a series of sensitivity analyses, including checking any differential pre-treatment time trends and verifying the consistency of the policy impact over time.

We expect that, within a location, the EPZ preferential policies benefit mostly to firms in the targeted sectors. While it may be possible that EPZ authorities provide firms operating in the targeted sectors of an EPZ with enhanced benefits (subsidies etc.), the main story relates to selection. Sectoral targeting induces that activities corresponding to locally selected priority sectors (so-called targeted) are over-represented in the EPZ's operations. Concretely firms which apply to enter in an EPZ are more likely to be accepted, hence to become exposed to the EPZ benefits, if their business is in line with the sectoral targeting.

We use Chinese Customs data to show that activities in EPZs mainly correspond to sectors listed as being priorities. The trade data from Chinese Customs provide export flows separately for EPZ locations and non EPZ locations within a 4-digit city level. We compute that the targeted sectors account for three quarters of the total exports emanating from the EPZ. In 2007, the median share is $91 \%$. This contrasts sharply with 
the corresponding shares of those sectors in the exports of the non-EPZ locations for the same list of cities. In 2007, the mean and median export shares of targeted sectors outside of EPZ locations are 0.51 and 0.49 respectively. On average in 2007 across sectors, the ratio of export shares for targeted versus non-targeted sectors is 1.7 times higher in EPZs than in non-EPZs. This suggests an effective selection of sectors that operate in the EPZs which follows the official priority list.

Interestingly, for more than one EPZ out of 4, exports of the targeted sectors account for more than $99 \%$ of the total exports. We interpret this as evidence that firms operating in the targeted sectors of an EPZ are more likely to be accepted into the EPZ and to establish themselves there. Within a city, targeted sectors are thus more exposed to the EPZ policy relative to sectors that are not awarded the priority status. We expect a differentiated export effect of the EPZ policy across sectors depending on the probability that they are allowed to operate in the newly established EPZs. Hence our estimation strategy identifies the EPZ policy efficiency and the magnification effect of density on exports filtering these impacts using a sector-level priority dummy, which captures the sector's exposure to the new regulations.

The establishment of an EPZ in a location is expected to boost exports through a number of channels. The first is preferential policies aimed at attracting firms that are not present in the locality. However it is also likely that pre-existing firms in the locality relocate to the EPZ to take advantage of the financial and logistic advantages offered. ${ }^{6}$ Exports from the locality will rise if the exports from these relocating firms expand thanks to

\footnotetext{
${ }^{6}$ The available data does not allow us to identify whether a firm is located within the boundaries of the local EPZ. Moreover even were identification possible, any strategic relocation inside the EPZ when it opens cannot be identified since firms that move to the EPZ receive a specific identification number that reflects their particular fiscal regime: we cannot match this new number to their previous (i.e. pre-EPZ) firm code.
} 
the export-promoting policies to which they have access in the EPZ. EPZ creation in a locality is also expected to encourage local export performance via spillovers to firms outside the EPZ. The first channel relates to input-output linkages, as firms in EPZs may purchase local intermediate goods. It is important to note that these sales from nonEPZ firms to EPZ firms are supposed to be recorded as exports by non-EPZ firms, given the extraterritorial nature of EPZs. Second, since foreign-invested firms (FIEs) dominate exports from EPZs, a clear policy objective with respect to EPZs is the facilitation of technology transfer from FIEs to domestic firms. EPZ firms are expected to generate technological spillovers to surrounding firms in part through the re-employment of skilled labor from EPZ to non-EPZ firms (Blonigen and Ma, 2010; Hale and Long, 2011). Last, there could be benefits from the export experience of multinationals. The possible channels of those export spillovers are information externalities, cost-sharing opportunities, and joint actions in export markets (Li and Liu, 2014; Mayneris and Poncet, 2015). ${ }^{7}$

\section{Data and indicators}

\subsection{EPZ establishment and sectoral focus}

We use the official list of 57 EPZs from the National Development and Reform Commission (NDRC). ${ }^{8}$ These are located in the four province-level cities (Beijing, Tianjin, Shanghai and Chongqing) and 39 prefecture-level cities. To facilitate the causal analysis of the repercussions of the EPZ establishment, we focus on the first wave of EPZs in

\footnotetext{
${ }^{7} \mathrm{Li}$ and Liu (2014) suggest that China's success in trade reflects its ability to attract foreign firms, notably in EPZs, and its subsequent ability to copy them. Mayneris and Poncet (2015) show in addition that the capacity of Chinese domestic firms to start exporting new varieties to new markets increases with the export activity of neighboring foreign firms.

${ }^{8}$ From the official website of China's National Development and Reform Commission: http://www.sdpc.gov.cn/zcfb/zcfbgg/200704/t20070406_126961.html.
} 
each location. ${ }^{9}$ Tables A-2 and A-3 list the EPZs included in our sample, indicating the location code (4-digit city code or 6-digit district code for province-level cities), name, establishment year and targeted sectors. Our sample then covers a total of $47 \mathrm{EPZs}$ established between 2000 and 2005. ${ }^{10}$ The geographical distribution of the EPZs is depicted in Appendix Figure A-1.

The description of priority sectors from the EPZ documents was matched to official sectors from the Chinese GBT industry classification. ${ }^{11}$ The sectors are defined following the Chinese sectoral classification at the 3-digit level. We use three documents to help us with this matching: a book from the National Bureau of Statistics on "Classification Notes of National Economic Industries" and two notes by the National Bureau of Statistics entitled "Classifications of Strategic Emerging Industries" and "Classifications of Electronic Information Products". When the keywords for the targeted sectors exactly match the description for a sector, we code the match as fully accurate. When some subjective judgment is required, we define the match as "not fully accurate". The robustness checks in Table 4 show that our results remain unchanged when we only use fully-accurate matches, or treat the targeted sectors for which identification is not fully accurate as not being targeted.

\footnotetext{
${ }^{9}$ Six cities established EPZs in different years. To ensure that our estimates capture the causal effect of EPZ opening, our sample is restricted to the years before the second wave of EPZs in these locations. The robustness checks in Table 4 show that our results are unchanged when these six cities are dropped from our sample.

${ }^{10}$ Among these $47 \mathrm{EPZs}, 5$ are located in different districts of Shanghai. Table 4 shows that our results are not affected by excluding these from our sample.

${ }^{11}$ The correspondence was carried out manually using keywords.
} 


\subsection{Export data}

The main export data source are the annual surveys conducted by the National Bureau of Statistics (NBS) in China. We use data from all survey years from 1998 to 2007. These firm-level surveys include balance-sheet data for all industrial state-owned firms and nonstate firms with sales above 5 million Yuan. Industry is defined here as including mining, manufacturing and public utilities. A comparison with the 2004 full census of industrial firms reveals that these firms (accounting for $20 \%$ of all industrial firms) employed roughly $70 \%$ of the industrial workforce and generated $90 \%$ of output and $98 \%$ of exports (Brandt et al., 2012). ${ }^{12}$ The set of available variables in the Chinese data set varies by year (Brandt et al., 2014). We use information on the number of employees, sales, capital, R\&D and exports. ${ }^{13}$ In the 2004 census year, employment was broken down by education, which allows us to calculate a skill ratio of employment with above-college education to total employment. The firm-level data is aggregated up to the 3-digit sector level for each location. Locations are identified by their 4-digit code for prefecture-level cities and 6-digit district code for province-level cities. Our final sample covers 47 locations that established an EPZ between 2000 and 2005, and 158 sectors. The firm information does not allow us to see whether it is established within the boundaries of an EPZ, as such the export performance in a location includes that from both EPZ firms and non-EPZ firms. Even were it possible to distinguish between these two firm types, firms that establish in EPZs are subject to a specific tax regime and receive a new identification number reflecting this change. So even if a firm relocates from another area into the EPZ when the latter opens

\footnotetext{
${ }^{12}$ Industry codes are made consistent across the entire period using the harmonized classification provided in Brandt et al. (2012).

${ }^{13} \mathrm{R} \& D$ data is available starting in 2001. We calculate capital using Brandt et al.'s (2012) procedure that converts estimates at the original purchase prices into real values that are comparable across time and firms.
} 
it is not possible to follow the firm over time in the data. There is thus no information on pre-existing export activities in EPZs prior to their establishment, precluding the use of a difference-in-differences approach at the level of the EPZ, as it is not the same firms in the EPZ pre- and post- EPZ establishment (Wang, 2013; Adler et al., 2013, Cheng, 2014). This is why we apply our econometric strategy to the wider locality level, which contains both EPZ and non-EPZ areas.

\subsection{Sector relatedness}

One of our contributions here is to evaluate whether the export benefits from the establishment of an EPZ depend on pre-existing productive capabilities and resources, as proxied by the density of the linkages between EPZ activities and local specialization (which is a locality-sector specific feature).

Our main variable of interest is density, which measures, for each locality-sector pair, the density of links to the local productive structure. We use the density indicator developed by Hidalgo et al. (2007) and Kali et al. (2013). The density for a good in a locality is calculated as the average of the good's bilateral proximities with the other goods that the locality exports with comparative advantage.

Following Hausmann and Klinger (2007) and Hidalgo et al. (2007), ${ }^{14}$ the bilateral proximity between two goods is based on world co-exporting probabilities. The products that are co-exported with another product in many countries are considered as an outcomebased measure of relatedness. This reflects the idea that co-exporting reveals similar requirements in terms of institutions, infrastructure, resources, technology, or some com-

\footnotetext{
${ }^{14}$ Who developed a Product Space representation that formalizes the notion of relatedness between products traded in the global economy.
} 
bination thereof. Producing and exporting computers is, for example, expected to require competencies, technology, inputs and production factors which are similar to those used to produce televisions. Hence, many countries should export both computers and televisions, yielding considerable proximity between the two products. Alternatively, since the necessary requirements for the production and export of products like T-shirts or toys are very different from those for computers, the proximity value between these two products and computers is likely much lower.

In detail, bilateral proximity (for each pair of products $i$ and $j$ ) is calculated using international country trade flows based on the probabilities that countries with comparative advantage in one of the goods ( $i$ or $j$ ) also have comparative advantage in the other. Revealed comparative advantages (RCAs) are defined using the index in Balassa (1965). A country is said to export a good with comparative advantage when the ratio of the export share of that product in the country's export basket to the analogous worldwide export share is greater than 1 . We define $\operatorname{Pr}(i \mid j)$ as the ratio of the number of countries with RCA in both $i$ and $j$ over the number of countries with RCA in $i$, and $\operatorname{Pr}(j \mid i)$, the ratio of the number of countries with $\mathrm{RCA}$ in both $i$ and $j$ over the number of countries with RCA in $j$. We calculate proximity as the minimum of those two pairwise conditional probabilities: $^{15}$

$$
\phi_{i, j}=\min [\operatorname{Pr}(i \mid j), \operatorname{Pr}(j \mid i)]
$$

This bilateral relatedness $\phi_{i, j}$ between products $i$ and $j$ is calculated for 5016 HS6 products, using data for 239 countries in 1997 from the $\mathrm{BACl}^{16}$ world trade dataset (Gaulier

\footnotetext{
${ }^{15}$ Taking the minimum of the conditional probabilities eliminates the problem arising when a country is the sole exporter of one particular good: the conditional probability of exporting any other good given this one good is one for all of the other goods exported by that country.

${ }^{16}$ This dataset, constructed using original COMTRADE data, provides bilateral trade flows. The BACl
} 
and Zignago, 2010). ${ }^{17}$ The matrix of these proximities characterizes the world product space. ${ }^{18}$ We aggregate this original 6-digit-product-level indicator to the 3-digit GBT industry classification, $\phi_{k, k^{\prime}}{ }^{19}$

Figure A-2 provides a visual summary of the distribution of the bilateral relatedness between sectors. It resembles a normal distribution. The bilateral relatedness measures are rather symmetric with few sector-level pairs being either very connected or very unrelated.

Our key indicator for the investigation of how EPZ efficiency depends on the density of the links of the targeted industry $k$ with the local productive structure in locality / is density $_{k}^{\prime}$ ). Revealed comparative advantages are calculated using the exports from the firm survey aggregated to the city level for the year prior the establishment of its first EPZ:

$$
\operatorname{Density}_{k}^{\prime}=\frac{\sum_{k^{\prime} \in R C A^{\prime}=1, k^{\prime} \neq k} \phi_{k, k^{\prime}}}{\sum_{k^{\prime} \neq k} \phi_{k, k^{\prime}}}
$$

The numerator above is the sum of sector $k^{\prime}$ 's proximities to the sector $k^{\prime}$ in which locality I has revealed comparative advantage $\left(R C A^{\prime}=1\right)$, while the denominator is the sum of the proximities to all sectors except $k$. The problem of reverse causality in our empirical exercise is limited by the way in which the density index is calculated. First, the density index is measured in the year prior the establishment of city l's first EPZ. Second, as indicated in Equation 2, the density variable (for a given city / and sector $k$ ) is calculated as the sum of bilateral proximities $\left(\phi_{k, k^{\prime}}\right)$, which are determined world-wide and hence dataset is downloadable from http://www.cepii.fr/anglaisgraph/bdd/baci.htm.

${ }^{17}$ The flow dataset is constructed using an original procedure that reconciles the declarations of exporters and importers. The harmonization procedure enables us to extend considerably the number of countries for which trade data are available, as compared to the original dataset.

${ }^{18}$ See Poncet and Starosta de Waldemar (2015) for some summary statistics on proximity.

${ }^{19}$ The concordance table between GBT sectors and HS6 products comes from Upward et al. (2013). Our final sample contains 158 sectors. 
cannot be suspected of being endogenous. The sum is furthermore over the sectors $k^{\prime}$ and excludes the sector $k$ for which location $/$ has an RCA. As such it does not incorporate any information on the export flows for sector $k$.

High density values indicate that locality / has comparative advantage in many industries that are closely related to sector $k$ : this sector is then densely-connected to the local productive structure. As in Kali et al. (2013), Hidalgo et al. (2007) and Poncet and Starosta de Waldemar (2015), density is considered as a proxy for product spillovers emanating from consistent specialization, such as knowledge externalities and economies of scale and scope spillovers.

Figure A-3 shows the distribution of the density indicator (in level) over our sample, for targeted and non-targeted sectors separately. The city-sector density variable is rather symmetrically distributed around the mean with few city-sector pairs being either very densely connected or very disconnected to the local production structure. Figure A4 shows the distribution of the average density indicator computed within cities across sectors. City-sector densities vary much less within cities than between them. The mean and median of the density indicator come out at 0.285 while the average standard deviation is 0.014 . These distribution statistics will be used to interpret the magnitude of the estimated coefficients in section 5.3. Our thought experiment will be an increase of a one standard deviation over the mean in within-city product density amounting to a $5 \%$ higher density $(0.014 / 0.285)$. 


\section{Empirical strategy}

We identify the effect of EPZ policies from the differential effect of EPZ establishment across targeted and non-targeted sectors. We estimate the following equation on our panel of sectoral export data for 47 locations $^{20}$ over 1998-2007:

$$
\ln \left(1+\text { Exports }_{l k t}\right)=\alpha \mathrm{EPZ}_{l t} \times \text { Target }_{l k}+\lambda_{l k}+\mu_{l t}+\nu_{k t}+\epsilon_{l k t}
$$

where Exports Ikt $_{\text {are }}$ are the-on-board export sales in industry $k$ in year $t$ at location $I$. $E P Z_{l t}$ equals one if location / hosts an EPZ in year $t$ and zero otherwise. Target ${ }_{1 k}$ is a dummy identifying sectors that are specifically targeted for the development of processing exports in the EPZ. ${ }^{21}$ Time-invariant characteristics that differ between sectors chosen for targeting and the other sectors in a location will be captured by location-sector fixed effects. Time-varying effects at the location and sector level are picked up by $\mu_{/ t}$ and $\nu_{k t}$ respectively. Shocks common to all sectors in a particular location or the demand for goods from a particular sector are hence controlled for. We run regressions with the dependent variable defined as the log of exports plus 1 , as we can then include zero export flows. ${ }^{22}$ We have around $54 \%$ of zeros in our database. We ensure that our findings do not solely reflect this specification and present robustness checks using alternative estimations methods to account for the presence of zero trade flows. A standard approach to incorporate the zero trade flows is the Poisson pseudo-maximum likelihood estimator (Santos Silva and Tenreyro, 2006). Santos Silva and Tenreyro (2011) show that it is generally well behaved,

\footnotetext{
${ }^{20}$ The model is estimated on the sample of 47 locations set out in Appendix Tables A-2 and A-3 that host an EPZ at some point over our study period (1998-2007).

${ }^{21}$ The summary statistics for all variables are presented in Table A-1.

${ }^{22}$ Zeroes are important because of endogenous selection. Failure to incorporate the zero trade flows results in biased coefficients (Helpman et al., 2008).
} 
even when the proportion of zeros in the sample is very large, as in our case. However, we encounter computation problems when we want to control for time-varying city and sector characteristics. We show that our results are robust to limiting the sample to positive flows (in logarithm), and to Poisson pseudo-maximum likelihood estimator with a reduced number of fixed effects. ${ }^{23}$

Our empirical strategy addresses the traditional endogeneity issue as it accounts for the inherent selection bias in the location of EPZs. As Li and Liu (2014), among others, have noted, compared to cities which did not receive EPZs cities which did were much larger as reflected in population, GDP and exports. First, our sample only includes locations that did by 2005 host an EPZ, reducing the scope for confounders. Second, with the fixed effects, our estimates appeal to within changes (before and after EPZ establishment) that are different between targeted and non-targeted sectors. Our identification exploits variations in the expected impact of the EPZ policy by sector to isolate the direct causal effect on export promotion. Our main coefficient of interest is thus that on the triple interaction term $\alpha$. If the EPZ policy promotes a location's exports, we expect a relative increase in exports in targeted sectors relative to non-targeted sectors.

We furthermore allow the measured EPZ effect $(\alpha)$ to depend on the consistency of the sectoral target with the local productive structure. As was explained in Section 3.3, our proxy of sector relatedness at the location level is the density of links between the targeted sector and the other sectors in which the locality exports with comparative advantage (in logs). This is measured in the year prior the establishment of its first EPZ, so that it captures pre-existing productive knowledge, abstracting from the reverse causality coming

\footnotetext{
${ }^{23}$ Ideally, we would also check for robustness using a Heckman two-stage procedure, but we lack a convincing exclusion restriction (Head and Mayer, 2014).
} 
from subsequent export performance. In Section 5.2 we will augment the specification in Equation 3 via the interaction of the $\mathrm{EPZ}_{l t} \times$ Target $_{/ k}$ term with the density for locationsector pair $/ k$, controlling for the interaction between $E P Z_{l t}$ and Density $\left.\right|_{l k}$.

As industries vary in terms of their intrinsic density of links to the local productive structure, we expect preferential EPZ policies to have a greater effect on activities when there is more pre-existing productive knowledge. This particularity allows us to determine the causal effect of the EPZ policy on exports, even if the selection of EPZs and targeted sectors was not exogenous to economic activity. We thus filter out the impact of the EPZ using the density index, which captures the intrinsic predisposition to benefit from exportpromoting policies. Our triple-difference estimation compares i) locations before and after the EPZ establishment (the first difference), ii) targeted vs. non-targeted sectors (the second difference), and iii) sectors with higher vs. lower density (the third difference).

We cluster regression standard errors at the location-year level, to account for the correlation between sectors within the treated units (here the locations in a given year).

\section{Results}

\subsection{Benchmark results}

In column 1 of Table 1 we estimate Equation (3) without the dyadic (location-year, sectoryear, location-sector) fixed effects, including only location, sector and year dummies. Theoretically, the impact of the EPZ on exports is captured by the EPZ $Z_{\text {It }}$ variable once the location fixed effects have picked up any intrinsic performance differences between locations, and the year fixed effects any time-varying shocks affecting the entire Chinese 
economy. The estimated coefficient on $\mathrm{EPZ}_{l t}$ is positive but insignificant, suggesting no link between the establishment of an EPZ and export performance. This insignificance is in line with the fact that not all sectors within a location are accepted to operate into EPZs and hence are exposed to the EPZ policy. In column 2, we interact the EPZ $Z_{\text {It }}$ variable with a dummy denoting sectoral targeting, which is specific to the location after picking up sectoral-specific effects via sector-year dummies. This interaction term, EPZ $Z_{l t} \times \operatorname{Target}_{l k}$, is positive and significant, showing a greater export performance of the sectors targeted by the EPZs' export-promoting policies compared to the other sectors. We add locationyear dummies in column 3, so that $\mathrm{EPZ}_{\text {It }}$ drops out, which however does not affect the size and significance of $\alpha$. The next three columns verify that the results of column 3 are robust to checks related to the role of zero-value export flows. Column 4 uses the Poisson pseudo-maximum likelihood estimator, a standard approach to incorporate the zero trade flows (Santos Silva and Tenreyro, 2006). Column 5 limits the sample to positive export flows (in logarithm). The point estimates for our key interaction term between $\mathrm{EPZ}_{l t} \times$ Target $_{l k}$ are fairly comparable throughout the specifications and suggest a relative expansion of export activities of targeted sectors after the establishment of an EPZ. This gives us confidence in analyzing the results using our benchmark explained variable, In (1+exports), with additional fixed effects.

Column 6 shows the results from our benchmark specification in Equation (3) which includes fixed effects at the location-year, sector-year and location-sectoral levels. Here all of the characteristics that may have led to the choice of EPZ establishment in a particular location are picked up by the location-year fixed effects, while any intrinsic reason behind the decision to target a specific sector in a location is captured by the 
Table 1 - Benchmark results: EPZ policy and export values

\begin{tabular}{|c|c|c|c|c|c|c|}
\hline \multirow[t]{2}{*}{ Dependent variable: } & \multicolumn{3}{|c|}{$\operatorname{Ln}\left(1+\right.$ Exports $\left._{/ k t}\right)$} & \multirow{2}{*}{$\begin{array}{l}\text { Exports/kt } \\
\text { PPML } \\
\text { (4) }\end{array}$} & \multirow{2}{*}{$\begin{array}{c}\operatorname{Ln}\left(\text { Exports }_{/ k t}\right) \\
\text { (5) }\end{array}$} & \multirow{2}{*}{$\begin{array}{c}\operatorname{Ln}\left(1+\text { Exports }_{\mid k t}\right) \\
(6)\end{array}$} \\
\hline & (1) & (2) & (3) & & & \\
\hline $\mathrm{EPZ}_{\text {It }}$ & $\begin{array}{c}0.059 \\
(0.047)\end{array}$ & $\begin{array}{l}-0.079 \\
(0.054)\end{array}$ & & & & \\
\hline $\mathrm{EPZ}_{\mid t} \times$ Target $_{/ k}$ & & $\begin{array}{c}0.304^{a} \\
(0.058)\end{array}$ & $\begin{array}{c}0.346^{a} \\
(0.0576)\end{array}$ & $\begin{array}{c}0.727^{a} \\
(0.156)\end{array}$ & $\begin{array}{c}0.253^{a} \\
(0.062)\end{array}$ & $\begin{array}{c}0.066^{a} \\
(0.024)\end{array}$ \\
\hline Target $_{/ k}$ & & $\begin{array}{c}0.072^{c} \\
(0.038)\end{array}$ & $\begin{array}{c}0.053 \\
(0.037)\end{array}$ & $\begin{array}{l}-0.177 \\
(0.109)\end{array}$ & $\begin{array}{c}0.008 \\
(0.045)\end{array}$ & \\
\hline Observations & 72,048 & 72,048 & 72,048 & 70,626 & 32,894 & 72,048 \\
\hline R-squared & 0.467 & 0.468 & 0.489 & & 0.382 & 0.884 \\
\hline Fixed effects & & & & & & \\
\hline Sector & Yes & Yes & Yes & Yes & Yes & \\
\hline Location & Yes & Yes & & & & \\
\hline Year & Yes & Yes & & & & \\
\hline Location-Year & No & No & Yes & Yes & Yes & Yes \\
\hline Location-Sector & No & No & No & No & No & Yes \\
\hline Sector-Year & No & No & No & No & No & Yes \\
\hline
\end{tabular}

Exports $_{/ k t}$ refers to the exported value in industry $k$ at year $t$ for location $/$. PPML stands for Poisson pseudo maximum likelihood estimator. Heteroskedasticity-robust standard errors clustered at the location-year level appear in parentheses. ${ }^{a},{ }^{b}$ and ${ }^{c}$ indicate significance at the $1 \%, 5 \%$ and $10 \%$ confidence levels.

location-sector dummies. Compared to column $3, \alpha$ is reduced but remains positive and significant, suggesting that preferential treatment did prompt a relative rise in exports. As measured in column 6 of Table 1 , sectors that are awarded priority status to settle in EPZs, hence to be eligible to the EPZ benefits, export $6.6 \%$ more in the post-EPZ establishment period, relative to the pre-EPZ period and non-targeted sectors.

We check in Table 2 that our finding of enhanced export performance for sectors treated as priority by the local government in their efforts to develop export-processing activities does not solely reflect pre-existing (positive) different trends. One possible explanation for any estimated export benefit is positive selection, whereby local authorities deliberately "pick the winners" and grant preferential policies to sectors with better prior performance. We test whether we observe a significant relative expansion of to-be-targeted sectors prior to the establishment of the EPZ. 
Table 2 - EPZ policy and export values: Checking the parallel-trend assumption

\begin{tabular}{|c|c|c|}
\hline \multirow[t]{2}{*}{ Dependent variable: } & \multicolumn{2}{|c|}{$\operatorname{Ln}\left(1+\right.$ Exports $\left._{/ k t}\right)$} \\
\hline & (1) & (2) \\
\hline \multirow[t]{2}{*}{$\mathrm{EPZ}_{l, t-7} \times$ Target $_{/ k}$} & -0.0388 & \\
\hline & $(0.151)$ & \\
\hline \multirow[t]{2}{*}{$\mathrm{EPZ}_{l, t-6} \times$ Target $_{l k}$} & 0.0970 & \\
\hline & $(0.0638)$ & \\
\hline \multirow[t]{2}{*}{$\mathrm{EPZ}_{l, t-5} \times$ Target $_{l k}$} & $0.139^{b}$ & $0.0944^{c}$ \\
\hline & $(0.0687)$ & $(0.0568)$ \\
\hline \multirow{2}{*}{$\mathrm{EPZ}_{l, t-4} \times$ Target $_{/ k}$} & -0.00140 & 0.00243 \\
\hline & $(0.0411)$ & $(0.0414)$ \\
\hline \multirow[t]{2}{*}{$\mathrm{EPZ}_{l, t-3} \times$ Target $_{l k}$} & -0.0826 & -0.0822 \\
\hline & $(0.0643)$ & $(0.0640)$ \\
\hline \multirow[t]{2}{*}{$\mathrm{EPZ}_{l, t-2} \times$ Target $_{/ k}$} & -0.0356 & -0.0333 \\
\hline & $(0.0365)$ & $(0.0367)$ \\
\hline \multirow[t]{2}{*}{$\mathrm{EPZ}_{l, t-1} \times$ Target $_{/ k}$} & -0.00548 & -0.00428 \\
\hline & $(0.0325)$ & $(0.0324)$ \\
\hline \multirow{2}{*}{$\mathrm{EPZ}_{l, t+1} \times$ Target $_{l k}$} & 0.0242 & 0.0243 \\
\hline & $(0.0354)$ & $(0.0352)$ \\
\hline \multirow[t]{2}{*}{$\mathrm{EPZ}_{l, t+2} \times$ Target $_{l k}$} & 0.0201 & 0.0223 \\
\hline & $(0.0390)$ & $(0.0388)$ \\
\hline \multirow[t]{2}{*}{$\mathrm{EPZ}_{l, t+3} \times$ Target $_{l k}$} & $0.0959^{b}$ & $0.0925^{b}$ \\
\hline & $(0.0437)$ & $(0.0438)$ \\
\hline \multirow[t]{2}{*}{$\mathrm{EPZ}_{I, t+4} \times$ Target $_{l k}$} & $0.114^{b}$ & $0.113^{b}$ \\
\hline & $(0.0492)$ & $(0.0489)$ \\
\hline \multirow[t]{2}{*}{$\mathrm{EPZ}_{l, t+5} \times$ Target $_{l k}$} & $0.110^{b}$ & $0.117^{b}$ \\
\hline & $(0.0486)$ & $(0.0455)$ \\
\hline \multirow{2}{*}{$\mathrm{EPZ}_{l, t+6} \times$ Target $_{l k}$} & $0.155^{b}$ & \\
\hline & $(0.0626)$ & \\
\hline \multirow[t]{2}{*}{$\mathrm{EPZ}_{1, t+7} \times$ Target $_{/ k}$} & 0.0843 & \\
\hline & $(0.0763)$ & \\
\hline Observations & 72,048 & 72,048 \\
\hline R-squared & 0.885 & 0.885 \\
\hline Location-Year fixed effects & Yes & Yes \\
\hline Sector-Year fixed effects & Yes & Yes \\
\hline Location-Sector fixed effects & Yes & Yes \\
\hline
\end{tabular}

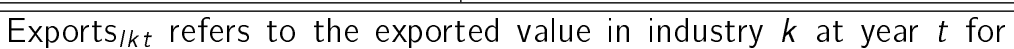
location $I$. Heteroskedasticity-robust standard errors clustered at the location-year level appear in parentheses. ${ }^{a},{ }^{b}$ and ${ }^{c}$ indicate significance at the $1 \%, 5 \%$ and $10 \%$ confidence levels. 
We hence reproduce column 4 of Table 1 , but now decompose $E P Z_{\text {It }}$ into various year dummies before and after EPZ creation, keeping the year in which the EPZ was established in the locality as the benchmark. The dummy denoted by $E P Z_{l, t-3}$ equals one for location I three years prior the establishment of its first EPZ and zero otherwise, while $E P Z_{l, t+3}$ equals one year three years after location / established its first EPZ and zero otherwise. In the case of an EPZ established in 2002 then, $E P Z_{l, t-3}$ is 1 in 1999 and $E P Z_{l, t+3}$ is 1 in 2005. In column 1 we include 14 year dummies, 7 for the years prior to EPZ creation and 7 after to see how $\alpha$ evolves over time. The $E P Z_{1, t-7}$ dummy lumps together the observations 7 or more years prior to the establishment of the $E P Z$, while $E P Z_{l, t+7}$ lumps together the observations 7 years or more post-establishment. In column 2 we include 10 year effects as $E P Z_{l, t-5}$ groups observations 5 or more years earlier and $E P Z_{l, t+5}$ observations 5 or more years later.

The estimated coefficients pre-EPZ establishment alternates between positive and negative but are insignificant for all but one period 5 years prior to the EPZ opening. The insignificant coefficients on the yearly interaction terms prior to EPZ establishment show that the change in export patterns in targeted and non-targeted sectors was similar in the years prior to the EPZ policy. This hence suggests that the sectors selected as priorities for preferential EPZ policies were neither better nor worse performers ex ante compared to the non-selected sectors. The coefficients on the year dummies after EPZ establishment are by contrast all positive, in line with our aggregate results. The coefficients do also become larger over the years, suggesting that export performance in targeted sectors increases over time, compared to non-targeted sectors. The estimates become significant from three years after the EPZ establishment. This is consistent with the delays inher- 
ent to the development of the technological and export spillovers from EPZ to non-EPZ firms. Overall, our results confirm the main message of the efficiency of the EPZ policy in generating the expected export gains. EPZ export patterns became increasingly biased in favor of sectors awarded the priority status to be eligible to the EPZ benefits over time.

\subsection{The Magnification Effect of Density}

Table 3 investigates whether the positive effect of EPZ on export performance observed in the previous section masks substantial sectoral heterogeneity according to the targeted activities' ability to find and exploit the required capabilities and resources. The growing literature on the gains from the availability of required capabilities and resources (Hidalgo et al., 2007; Lin, 2012) predicts that preferential export policies should especially benefit activities that relate to local comparative advantage. We test for a role for the density of links between the targeted sector and the other activities in the location by augmenting our benchmark specification from column 6 in Table 1 with the interaction of the $\mathrm{EPZ}_{1 t} \times$ Target $_{l k}$ term with the density for location-sector pair $/ k$, while controlling for the interaction between $E P Z_{l t}$ and Density $y_{l k}$. The intrinsic gains from the adequation between sectoral activities and the local productive structure are accounted for by timevarying sector fixed effects. The term $E P Z_{l t} \times \ln$ Density $_{l k}$ measures the extent to which the overall impact of EPZ establishment on exports varies with density, and the term $\mathrm{EPZ}_{l t} \times$ Target $_{l k} \times$ In Density I $_{k}$ captures the additional effect specific to the targeted sectors. Both interactions attract positive and significant estimated coefficients. The positive and significant coefficient on $\mathrm{EPZ}_{l t} \times \ln$ Density $_{l k}$ indicates that the positive export repercussions from the EPZ establishment are stronger for sectors that have dense links with those currently produced in the locality irrespective of their priority status. The 
positive and significant coefficient on the triple-interaction coefficient $E P Z_{l t} \times \operatorname{Target}_{l k} \times$ In Density ${ }_{I k}$ further suggests additional export gains for the priority sectors which are also proportional to the sector's consistency with the local productive structure.

Column 1 of Table 3 reports the baseline using $\log (1+$ exports $)$ as the dependent variable while the remaining columns undertake some robustness checks related to the role of zerovalue export flows. Column 2 limits the sample to positive flows (in logarithm). Column 3 reports the PPML estimates with a reduced number of fixed effects since including more than city-year and sector fixed effects is not feasible. For comparison, we display in columns 4 and 5 results of OLS regressions for $\log (1+$ exports) and $\log$ (exports) with the same fixed effects. The finding of a magnification effect of the export gains from the EPZ policy when density is high is confirmed throughout the specifications. The point estimate on the triple interaction term rises in column 3 but is not statistically different from the results in columns 1 and 2 .

\subsection{Magnitude of the effects}

Several thought experiments can provide an idea of the magnitude of EPZ-efficiency magnification from pre-existing productive knowledge measured so far.

We first explore by how much exports grow following the EPZ establishment when comparing a sector at the median of the distribution of density in the city to another sector characterized by a one standard deviation higher density. Based on the within-city distribution of the density measure reported in Figure A-4 an increase of a one standard deviation over the mean in within-city product density amounts to a $5 \%$ higher density $(0.014 / 0.285)$. As measured in column 1 of Table 3 , such a difference in the density 
Table 3 - EPZ policy and export values: conditioning on sector relatedness

\begin{tabular}{|c|c|c|c|c|c|}
\hline "Dependent variable: & $\begin{array}{c}\operatorname{Ln}\left(1+\text { Exports }_{/ k t}\right) \\
(1)\end{array}$ & $\begin{array}{c}\operatorname{Ln}\left(\text { Exports }_{/ k t}\right) \\
\text { (2) }\end{array}$ & $\begin{array}{c}\text { Exports } / k t \\
\text { PPML } \\
\text { (3) }\end{array}$ & $\begin{array}{c}\operatorname{Ln}\left(1+\text { Exports }_{/ k t}\right) \\
\text { (4) }\end{array}$ & $\begin{array}{c}\operatorname{Ln}\left(\text { Exports }_{\mid k t}\right) \\
\text { (5) }\end{array}$ \\
\hline $\mathrm{EPZ}_{1 t} \times$ Target $_{/ k}$ & $\begin{array}{l}0.334^{a} \\
(0.0967)\end{array}$ & $\begin{array}{c}0.232 \\
(0.154)\end{array}$ & $\begin{array}{l}1.159^{a} \\
(0.394)\end{array}$ & $\begin{array}{l}1.037^{a} \\
(0.125)\end{array}$ & $\begin{array}{l}0.587^{a} \\
(0.184)\end{array}$ \\
\hline $\mathrm{EPZ}_{l t} \times \operatorname{Target}_{l k} \times \ln$ Density $_{l k}$ & $\begin{array}{c}0.218^{a} \\
(0.0702)\end{array}$ & $\begin{array}{l}0.224^{c} \\
(0.126)\end{array}$ & $\begin{array}{l}0.585^{c} \\
(0.338)\end{array}$ & $\begin{array}{c}0.602^{a} \\
(0.0861)\end{array}$ & $\begin{array}{l}0.321^{b} \\
(0.152)\end{array}$ \\
\hline $\mathrm{EPZ}_{l t} \times \ln$ Density $_{l k}$ & $\begin{array}{l}1.768^{a} \\
(0.221)\end{array}$ & $\begin{array}{l}1.123^{a} \\
(0.313)\end{array}$ & $\begin{array}{l}5.680^{a} \\
(0.587)\end{array}$ & $\begin{array}{l}6.256^{a} \\
(0.426)\end{array}$ & $\begin{array}{l}3.915^{a} \\
(0.413)\end{array}$ \\
\hline Target $_{l k}$ & & & $\begin{array}{l}-0.0386 \\
(0.0972) \\
\end{array}$ & $\begin{array}{l}0.0796^{b} \\
(0.0355) \\
\end{array}$ & $\begin{array}{c}0.0260 \\
(0.0443) \\
\end{array}$ \\
\hline Observations & 72,048 & 32,894 & 72,048 & 72,048 & 32,894 \\
\hline R-squared & 0.885 & 0.856 & & 0.503 & 0.388 \\
\hline $\begin{array}{l}\text { Fixed effects } \\
\text { Location-Year } \\
\text { Location-Sector } \\
\text { Sector-Year } \\
\text { Sector }\end{array}$ & $\begin{array}{l}\text { Yes } \\
\text { Yes } \\
\text { Yes }\end{array}$ & $\begin{array}{l}\text { Yes } \\
\text { Yes } \\
\text { Yes }\end{array}$ & $\begin{array}{l}\text { Yes } \\
\text { No } \\
\text { No } \\
\text { Yes } \\
\end{array}$ & $\begin{array}{l}\text { Yes } \\
\text { No } \\
\text { No } \\
\text { Yes } \\
\end{array}$ & $\begin{array}{l}\text { Yes } \\
\text { No } \\
\text { No } \\
\text { Yes } \\
\end{array}$ \\
\hline
\end{tabular}

Exports $/ k t_{t}$ refers to the exported value in industry $k$ at year $t$ for location $/$. PPML stands for Poisson pseudo maximum likelihood estimator. Heteroskedasticity-robust standard errors clustered at the location-year level appear in parentheses. ${ }^{a},{ }^{b}$ and ${ }^{c}$ indicate significance at the $1 \%, 5 \%$ and $10 \%$ confidence levels.

of links across sectors leads to a relative increase in annual exports of $9 \%$. This is an economically significant change. We can nonetheless put this in perspective by comparing it to the substantial average annual figure for export growth of $16 \%$ over this period.

The point estimate for the triple-interaction coefficient $E P Z_{l t} \times \operatorname{Target}_{l k} \times \ln$ Density $_{l k}$ is 8 times smaller than the double-interaction coefficient of $E P Z_{l t} \times \ln$ Density $_{l k}$. The observed magnification effect of a 5\% density rise on EPZ-policy efficiency is nevertheless reinforced for targeted sectors which are the most exposed to the policy. Our results suggest an additional 1.1 percentage point of exports for sectors that are awarded priority status.

Another approach to illustrate the results on the key role of the density of links is to compare the export gains from the establishment of an EPZ for a sector at the $10^{\text {th }}$ percentile and a sector at the $90^{\text {th }}$ percentile of the within-city distribution of density. 
The coefficients from column 1 in Table 3 indicate that, all things being equal, the export gains from the establishment of an EPZ are higher for a sector at the $90^{\text {th }}$ percentile relative to a sector at the $10^{\text {th }}$ percentile of the distribution of density, by a factor 1.24 $[1.768 \times 0.134]$ for the non-targeted sectors. This factor is reinforced for sectors that are selected to benefit from the EPZ policy and rises to 1.27 for these targeted sectors. We hence find additional export gains for the priority sectors that are economically significant.

\subsection{Robustness checks}

Table 4 verifies that EPZ-efficiency magnification from pre-existing productive knowledge is robust to various checks related to the definition of the explanatory variable and the identification of the year of EPZ establishment and sectoral targeting.

Column 1 redefines $E P Z_{I t}$, the dummy for location / hosting its first established EPZ in year $t$ and 0 otherwise, using the date of the EPZ's first export instead of the date of its official approval ( $\mathrm{Li}$ and Liu, 2014). ${ }^{24}$ The resulting estimates are virtually identical to those from the benchmark (column 1 of Table 3 ).

Columns 2 and 3 address the instances where a qualitative approach was used to match the official description of EPZ priority activities to sectors from the Chinese GBT industry classification (see Section 3.1). In column 2 the non-accurately matched targeted sectors are simply dropped, resulting in $20 \%$ fewer observations. Our estimates here thus result from the comparison of (accurately-matched) targeted sectors and non-targeted sectors

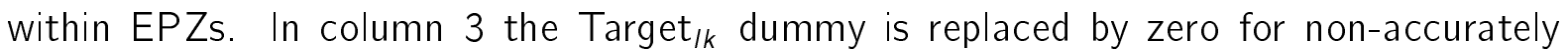
matched targeted sectors. In both columns, the relevant coefficients remain positive and

\footnotetext{
${ }^{24}$ The date of first EPZ export is found in the trade data from Chinese Customs, which provide export flows aggregated by 5-digit location. EPZ exports are identified by the fifth digit being equal to 5 .
} 
Table 4 - Conditioning effect of sector relatedness: Robustness checks (1)

\begin{tabular}{|c|c|c|c|}
\hline Dependent variable: & Exports & Exports & Exports \\
\hline Definition & $\begin{array}{c}E P Z_{I t} \\
\text { customs definition } \\
(1)\end{array}$ & $\begin{array}{c}\text { Drop non } \\
\text { accurate Target } / k \\
\text { (2) }\end{array}$ & $\begin{array}{l}\text { Non accurate } \\
\text { Target }_{l k}=0 \\
\text { (3) }\end{array}$ \\
\hline $\mathrm{EPZ}_{l t} \times$ Target $_{l k}$ & $\begin{array}{l}0.405^{a} \\
(0.104)\end{array}$ & $\begin{array}{c}0.432^{a} \\
(0.127)\end{array}$ & $\begin{array}{c}0.315^{a} \\
(0.118)\end{array}$ \\
\hline $\mathrm{EPZ}_{l t} \times$ Target $_{l k} \times \ln$ Density $_{l k}$ & $\begin{array}{c}0.244^{a} \\
(0.0765)\end{array}$ & $\begin{array}{c}0.260^{a} \\
(0.0945)\end{array}$ & $\begin{array}{c}0.186^{b} \\
(0.0889)\end{array}$ \\
\hline $\mathrm{EPZ}_{l t} \times \ln$ Density $_{l k}$ & $\begin{array}{l}1.588^{a} \\
(0.269)\end{array}$ & $\begin{array}{l}1.744^{a} \\
(0.241)\end{array}$ & $\begin{array}{l}1.879^{a} \\
(0.221)\end{array}$ \\
\hline $\begin{array}{l}\text { Observations } \\
\text { R-squared }\end{array}$ & $\begin{array}{c}72,048 \\
0.885\end{array}$ & $\begin{array}{c}57,496 \\
0.884\end{array}$ & $\begin{array}{c}72,048 \\
0.885\end{array}$ \\
\hline $\begin{array}{l}\text { Location-Year fixed effects } \\
\text { Sector-Year fixed effects } \\
\text { Location-Sector fixed effects }\end{array}$ & $\begin{array}{l}\text { Yes } \\
\text { Yes } \\
\text { Yes }\end{array}$ & $\begin{array}{l}\text { Yes } \\
\text { Yes } \\
\text { Yes }\end{array}$ & $\begin{array}{l}\text { Yes } \\
\text { Yes } \\
\text { Yes }\end{array}$ \\
\hline
\end{tabular}

Heteroskedasticity-robust standard errors clustered at the location-year level appear in parentheses. ${ }^{a},{ }^{b}$ and ${ }^{c}$ indicate significance at the $1 \%, 5 \%$ and $10 \%$ confidence levels.

significant, confirming the magnification effect of density on EPZ-policy efficiency.

Table 5 provides additional robustness checks to see whether the export-increasing effect of EPZ policy which is magnified by consistency with sectoral focus is driven by certain specific locations. The two first columns drop localities that are clearly different from the others in terms of location and policy particularities that made them more likely to benefit from export-promotion policies (Amiti and Freund, 2010; Wang and Wei, 2010).

In column 1 observations from the four province-level municipalities (Beijing, Tianjin, Shanghai and Chongqing) are dropped. These four "super cities" stand out by their smaller size, greater income and enhanced political autonomy.

Our results continue to hold, so that our findings of the efficiency of the EPZ program conditional on sectoral density are not driven by these particular locations. Column 2 considers locations where several waves of EPZ establishment occurred. Four prefecture-level cities $^{25}$ established additional EPZs after the first one. To ensure that our estimates ap-

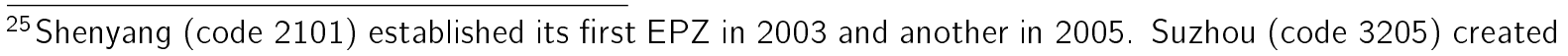


Table 5 - Conditioning effect of sector relatedness: Robustness checks (2)

\begin{tabular}{|c|c|c|c|}
\hline Dependent variable: & \multicolumn{3}{|c|}{ Exports of industry $k$ in year $t$ at location $l$} \\
\hline Sample & $\begin{array}{c}\text { Drop } \\
\text { province-level } \\
\text { locations } \\
(1)\end{array}$ & $\begin{array}{c}\text { Drop } \\
\text { pluri-EPZ } \\
\text { locations } \\
(2)\end{array}$ & $\begin{array}{c}\text { Drop } \\
\text { highly-targeted } \\
\text { sectors } \\
\text { (3) }\end{array}$ \\
\hline $\mathrm{EPZ}_{l t} \times$ Target $_{l k}$ & $\begin{array}{c}0.293^{a} \\
(0.0885)\end{array}$ & $\begin{array}{c}0.353^{a} \\
(0.105)\end{array}$ & $\begin{array}{c}0.214^{b} \\
(0.0967)\end{array}$ \\
\hline $\mathrm{EPZ}_{l t} \times \ln$ Density $_{l k}$ & $\begin{array}{l}1.546^{a} \\
(0.224)\end{array}$ & $\begin{array}{l}1.846^{a} \\
(0.237)\end{array}$ & $\begin{array}{c}1.698^{a} \\
(0.220)\end{array}$ \\
\hline $\mathrm{EPZ}_{\mid t} \times$ Target $_{l k} \times \ln$ Density $_{I k}$ & $\begin{array}{c}0.178^{a} \\
(0.0676)\end{array}$ & $\begin{array}{c}0.225^{a} \\
(0.0746)\end{array}$ & $\begin{array}{c}0.131^{c} \\
(0.0693)\end{array}$ \\
\hline $\begin{array}{l}\text { Observations } \\
\text { R-squared }\end{array}$ & $\begin{array}{c}59,408 \\
0.895\end{array}$ & $\begin{array}{l}67,94 \\
0.879\end{array}$ & $\begin{array}{c}67,032 \\
0.884\end{array}$ \\
\hline $\begin{array}{l}\text { Location-Year fixed effects } \\
\text { Sector-Year fixed effects } \\
\text { Location-Sector fixed effects }\end{array}$ & $\begin{array}{l}\text { Yes } \\
\text { Yes } \\
\text { Yes }\end{array}$ & $\begin{array}{l}\text { Yes } \\
\text { Yes } \\
\text { Yes }\end{array}$ & $\begin{array}{l}\text { Yes } \\
\text { Yes } \\
\text { Yes }\end{array}$ \\
\hline
\end{tabular}

Heteroskedasticity-robust standard errors clustered at the location-year level appear in parentheses. ${ }^{a},{ }^{b}$ and ${ }^{c}$ indicate significance at the $1 \%, 5 \%$ and $10 \%$ confidence levels.

propriately capture the causal effect of EPZ opening, our sample so far has been restricted to the years before the second wave of EPZs in those four locations. The results in column 2 are obtained by dropping all observations from those four cities. The results in this restricted sample are in line with the benchmark results in Table 3. In column 3, we drop the sectors that are targeted by most EPZs, since they may share specific features related to their higher technology content that enhance their capacity to benefit from EPZ preferential treatment. ${ }^{26}$ The finding of growing export gains from EPZ establishment with the density of links with the local productive structure continues to hold.

Our analysis so far exploits only data from 23 locations in which the EPZs are established. Our hypothesis is that other locations are likely to differ notably in terms of their existing new EPZs in 2003 and 2005 after the first wave in 2000, Ningbo (code 3302) established a second EPZ in 2005 after the first in 2002, Guangzhou (code 4401) established its first EPZ in 2000 and a second in 2005.

${ }^{26}$ We identify 11 sectors that were targeted by at least $46 \mathrm{EPZs}$ (out of 47 ). These belong to the two-digit sectors of the manufacture of special equipment (code 36), manufacture of electric machines and equipment (code 39) or manufacture of telecommunication equipments, computers and other electric equipment (code 40). In detail, these correspond to the following 3-digit codes: 362, 366, 368, 391, 392, 393, 394, 403, 404, 405 and 406. 
production structure hence dampening the comparability of the zones with and without the policy, and hence the reliability of the resulting estimates. We nevertheless need to check that our results do not solely reflect our sample strategy selection and that they hold when we include other locations in the sample. ${ }^{27}$ Note that the dummies $E P Z_{l t}$ and Target $_{l k}$ are equal to zero for these control locations. Hence as our regressions include location-year and location-sector fixed effects, the sample extension mainly affects the point estimates for the sector-year dummies. These sector-year fixed effects are nevertheless crucial as they establish the benchmark to which the performance of targeted sectors in EPZs is measured. Table 6 reproduces our benchmark estimates (column 4 of Table 1 and column 1 of Table 3) looking at three different sample extensions. Columns 1 and 2 consider the full sample of locations. Columns 3 and 4 cover all the locations belonging to the 23 provinces that host an EPZ in 2005. Columns 5 and 6 extend the sample to 98 selected cities having a comparable density distribution to that in EPZs. ${ }^{28}$ Our main finding of a magnification effect of density on EPZ-policy efficiency is confirmed.

Table 7 investigates the robustness of the results to omitted variables which might be correlated with the sectoral pattern of the density of links. We test whether the relative rise in exports in sectors with denser connections to the local productive structure simply reflects that these sectors account for a larger share of local employment or stand out in terms of capital intensity, innovation potential etc. Since densely-connected locationsector pairs are likely to differ in a variety of dimensions, the density variable could then reflect this difference and how it affects the efficiency of export-promotion measures. In column 1 , we account for relative sector size via the interaction of $E P Z_{l t} \times \operatorname{Target}_{/ k}$ with the

\footnotetext{
${ }^{27}$ We thank an anonymous referee for this suggestion.

${ }^{28}$ Our procedure identifies for each EPZ the location(s) having a comparable distribution of the density index using the equality test on matched data (Wilcoxon, 1945).
} 
Table 6 - Extended sample including non-EPZ locations

\begin{tabular}{|c|c|c|c|c|c|c|}
\hline Dependent variable: & \multicolumn{6}{|c|}{ Exported value in industry $k$ at year $t$ for location $l$} \\
\hline $\begin{array}{l}\text { Sample: adding non-EPZ locations } \\
\text { in the control group }\end{array}$ & All loc & tions & $\begin{array}{l}\text { All locat } \\
\text { the } 23 \\
\text { hostin } \\
\text { (3) }\end{array}$ & $\begin{array}{l}\text { ns from } \\
\text { ovinces } \\
\text { EPZs } \\
(4)\end{array}$ & $\begin{array}{l}\text { Selected } \\
\text { with co } \\
\text { density d } \\
\text { (5) }\end{array}$ & $\begin{array}{l}\text { cations } \\
\text { parable } \\
\text { cribution } \\
\text { (6) }\end{array}$ \\
\hline $\mathrm{EPZ}_{l t} \times$ Target $_{l k}$ & $\begin{array}{c}0.270^{a} \\
(0.0243)\end{array}$ & $\begin{array}{l}0.481^{a} \\
(0.104)\end{array}$ & $\begin{array}{c}0.262^{a} \\
(0.0242)\end{array}$ & $\begin{array}{l}0.475^{a} \\
(0.104)\end{array}$ & $\begin{array}{c}0.216^{a} \\
(0.0235)\end{array}$ & $\begin{array}{l}0.441^{a} \\
(0.101)\end{array}$ \\
\hline $\mathrm{EPZ}_{\mid t} \times \ln$ Density $_{l k}$ & & $\begin{array}{l}2.335^{a} \\
(0.257)\end{array}$ & & $\begin{array}{l}2.307^{a} \\
(0.254)\end{array}$ & & $\begin{array}{l}2.162^{a} \\
(0.242)\end{array}$ \\
\hline $\mathrm{EPZ}_{\mid t} \times$ Target $_{\mid k} \times \ln$ Density $_{l k}$ & & $\begin{array}{c}0.183^{b} \\
(0.073)\end{array}$ & & $\begin{array}{c}0.184^{b} \\
(0.073)\end{array}$ & & $\begin{array}{c}0.192^{a} \\
(0.071)\end{array}$ \\
\hline Observations & 565,008 & 565,008 & 487,588 & 487,588 & 226,888 & 226,888 \\
\hline $\mathrm{Nb}$ of locations & 359 & 359 & 310 & 310 & 145 & 145 \\
\hline R-squared & 0.858 & 0.859 & 0.860 & 0.860 & 0.874 & 0.875 \\
\hline Location-Year fixed effects & Yes & Yes & Yes & Yes & Yes & Yes \\
\hline Sector-Year fixed effects & Yes & Yes & Yes & Yes & Yes & Yes \\
\hline Location-Sector fixed effects & Yes & Yes & Yes & Yes & Yes & Yes \\
\hline
\end{tabular}

Heteroskedasticity-robust standard errors clustered at the location-year level appear in parentheses. ${ }^{a}$, ${ }^{b}$ and ${ }^{c}$ indicate significance at the $1 \%, 5 \%$ and $10 \%$ confidence levels.

employment share of industry $k$ in location / in the year prior the establishment of the city's first EPZ. This additional interaction term attracts a positive and significant coefficient, suggesting that the export gains from EPZ trade-promoting policies are greater for larger sectors. However, we continue to find that pre-existing productive knowledge magnifies the efficiency of the EPZ program. Column 2 follows the same strategy regarding capital intensity. The interaction of $E P Z_{l t} \times$ Target $_{l k}$ with the capital to labor ratio in industry $k$ in location I (measured in the year prior to the first EPZ establishment), yields results that are again very similar to the benchmark.

The conditioning effect of location-sector R\&D intensity is investigated in column 3, while column 4 adds the interaction of $\mathrm{EPZ}_{l t} \times$ Target $_{l k}$ with a proxy for skill intensity. $R \& D$ intensity is measured as the ratio of $R \& D$ expenses to sales reported in the 2001 annual survey (the earliest year for which this information is available). Skill intensity at the location-sector level is measured as the share of employees with at least college education (measured in 2004, as the breakdown of workers by education level is only 
Table 7 - The conditioning effect of sector relatedness: Robustness checks

\begin{tabular}{|c|c|c|c|c|c|}
\hline "Dependent variable: & & orts in indus & ry $k$ at yea & $t$ for locat & \\
\hline Sample & & Benchmark & olus additic & ial controls & \\
\hline & (1) & $(2)$ & (3) & (4) & (5) \\
\hline $\mathrm{EPZ}_{/ t} \times$ Target $_{/ k}$ & $0.279^{a}$ & $0.261^{a}$ & $0.329^{a}$ & $0.171^{c}$ & $0.308^{a}$ \\
\hline & $(0.0942)$ & $(0.0929)$ & $(0.0958)$ & $(0.0944)$ & $(0.0949)$ \\
\hline $\mathrm{EPZ}_{\mid t} \times \ln$ Density $_{l k}$ & $1.687^{a}$ & $1.765^{a}$ & $1.767^{a}$ & $1.720^{a}$ & $1.750^{a}$ \\
\hline & $(0.221)$ & $(0.222)$ & $(0.221)$ & $(0.219)$ & $(0.212)$ \\
\hline $\mathrm{EPZ}_{\mid t} \times$ Target $_{/ k} \times \ln$ Density $/ k$ & $0.220^{a}$ & $0.192^{a}$ & $0.217^{a}$ & $0.159^{b}$ & $0.207^{a}$ \\
\hline & $(0.0692)$ & $(0.0685)$ & $(0.0702)$ & $(0.0686)$ & $(0.0680)$ \\
\hline $\mathrm{EPZ}_{l t} \times$ Target $_{l k} \times$ Empl. share $_{l k}$ & $\begin{array}{l}8.156^{a} \\
(1.398)\end{array}$ & & & & \\
\hline $\mathrm{EPZ}_{l t} \times$ Target $_{l k} \times \mathrm{K} / \mathrm{L}_{l k}$ & & $\begin{array}{l}0.000593^{a} \\
(0.000150)\end{array}$ & & & \\
\hline $\mathrm{EPZ}_{l t} \times$ Target $_{l k} \times \mathrm{R} \& \mathrm{D}$ over sales $/ k$ & & & $\begin{array}{c}1.976 \\
(1.448)\end{array}$ & & \\
\hline $\mathrm{EPZ}_{l t} \times$ Target $_{/ k} \times$ skill ratio $/ k$ & & & & $\begin{array}{l}1.280^{a} \\
(0.147)\end{array}$ & \\
\hline $\mathrm{EPZ}_{\mid t} \times$ Target $_{l k} \times$ export share ${ }_{l k}$ & & & & & $\begin{array}{l}0.0986 \\
(0.153)\end{array}$ \\
\hline Observations & 72,048 & 72,048 & 72,048 & 72,048 & 72,048 \\
\hline R-squared & 0.885 & 0.885 & 0.885 & 0.885 & 0.885 \\
\hline Location-Year fixed effects & Yes & Yes & Yes & Yes & Yes \\
\hline Sector-Year fixed effects & Yes & Yes & Yes & Yes & Yes \\
\hline Location-Sector fixed effects & Yes & Yes & Yes & Yes & Yes \\
\hline
\end{tabular}

Heteroskedasticity-robust standard errors clustered at the location-year level appear in parentheses. ${ }^{a}$, ${ }^{b}$ and ${ }^{c}$ indicate significance at the $1 \%, 5 \%$ and $10 \%$ confidence levels.

available in the National Business Surveys for that year). In column 5, we turn to the possible confounding effect of export orientation and add the interaction term with the share of industry $k$ in the exports of location $I .{ }^{29}$ In all of the columns the message remains that EPZ policy in China proved most successful when targeted at sectors which matched pre-existing productive capabilities and knowledge, as proxied by density of links with the local productive structure.

Overall our results suggest that for an industrial policy to be efficient it is key to target sectors correctly, i.e. those well-connected to the local production structure. We can try to assess the extent to which Chinese EPZs have chosen the correct sectors so as to maximize their impact. Figure A-3 shows the distribution of our key density indicator for

\footnotetext{
${ }^{29}$ The export share at the location-industry level is calculated in the year prior to that of the first EPZ creation.
} 
targeted and non-targeted sectors separately. They are extremely similar. The distribution for targeted sectors is slightly to the right compared to that for non-targeted sectors. The average density for the targeted group is 0.294 compared to 0.278 for the non-targeted group. These statistics are a first hint that the sectoral focus of EPZs is not optimal. If we use the mean value of density in our sample as reported in Table A-1 and identify well-connected sectors as those with above mean-density we can compute the share of "correctly chosen" sectors by EPZs. We calculate that only $53 \%$ of the targeted sectors have above-mean density. This proportion is $47 \%$ for the non-targeted sectors. When looking at the EPZs individually, we identify that out of the 47,18 have an optimal focus (i.e. all targeted sectors are correctly chosen). By contrast in the case of $17 \mathrm{EPZs}$ none of the targeted sectors have above-mean density. Most of the EPZs that picked inappropriate sectors (i.e. unconnected to the local production structure) are located in the far-western part of China. ${ }^{30}$ This preliminary finding calls for more research on whether some conditions affect the capacity of authorities to be good at picking sectors properly. Possible candidates include the international trade exposure, the presence of foreign capital but also the career concern of the local officials who may have an incentive to follow national target sectors advocated by the central government even if they are not well-connected to the local production structure.

\section{Conclusion}

This paper has considered the impact of preferential export measures in EPZs in China. We use a data set of 47 localities that established an EPZ over the 1998-2007 period, and

\footnotetext{
${ }^{30}$ None of the targeted sectors have above-mean density in the EPZs of Inner Mongolia, Jilin, Anhui, Jiangxi, Henan, Hunan, Guangxi, Shaanxi, Chongqing and Xinjiang.
} 
exploit variations across time and sector targeting to determine the causal effect of the policy on firm export performance. We measure sizeable export benefits from the EPZ policy which are greater for sectors with denser links with the local productive structure. These export gains are further reinforced for targeted sectors which are the most exposed to the policy measure. Although this additional effect for targeted sectors is smaller, it is statistically and economically significant. Our results hence suggest that the consistency of the policy's focus on activities for which the required capabilities and resources are available magnifies EPZ efficiency. However, only 17 among of the 47 Chinese EPZs have a correct targeting, defined as the selection of well-connected sectors. By contrast for 18 other EPZs none of the targeted sectors have strong links with the local production structure. We leave it to future research to determine what may hinder the capacity of authorities to choose the sectoral focus properly.

More work is also required to allow us to explain the exact channels via which the sectoral density of links enhances the efficiency of EPZ policy. In addition, our approach does not allow us to determine what is behind these export gains. It remains an open question whether the better export performance from adequate sectoral focus comes from firms in EPZs or from spillovers from EPZ firms to non-EPZ areas of the locality. In the former case it would be interesting to know whether the EPZ firms are newly-established firms or whether they relocated to the EPZ from other areas in the locality. In the latter case of spillovers to non-EPZ exporters, it would be useful to know whether the benefits relate to technological or export spillovers. 


\section{References}

Akinci, G., and J. Crittle, 2008, Special Economic Zones: Performance, Lessons Learned, and Implications for Zone Development. The World Bank, Washington DC.

Alder, S., L. Shao and F. Zilibotti, 2013, The Effect of Economic Reform and Industrial Policy in a Panel of Chinese Cities, Working Paper. University of Zurich.

Amiti, M., and C. Freund, 2010, The Anatomy of China's Export Growth, In R. Feenstra and S.-J.Wei, Eds., China's Growing Role in World Trade. Chicago: University of Chicago Press, pp. 35-56.

Balassa, B., 1965, Trade Liberalisation and Revealed Comparative Advantage, Manchester School of Economic and Social Studies, 33, 99-123.

Blonigen, B.A., and A.C. Ma. 2010, Please Pass the Catch-Up: The Relative Performance of Chinese and Foreign Firms in Chinese Exports, In R. Feenstra and S.- J. Wei, Eds., China's Growing Role in World Trade, 475-509. Chicago: University of Chicago Press.

Brandt, L., J. Van Biesebroeck and Y. Zhang, 2012, Creative accounting or creative destruction? Firm-level productivity growth in Chinese manufacturing, Journal of Development Economics, 97 (2), 339-351.

Brandt, L., J. Van Biesebroeck and Y. Zhang, 2014, Challenges of working with the Chinese NBS firm-level data, China Economic Review, 30, 339-352.

Cai, J., A. Harrison and J. Lin, 2011, The Pattern of Protection and Economic Growth: Evidence from Chinese Cities, Working Paper.

Cheng, Y., 2014, Place-Based Policies in A Development Context: Evidence from China, 
Department of Economics, UC Berkeley, mimeo.

Crozet, M. and F. Trionfetti, 2013, Firm-Level Comparative Advantage, Journal of International Economics, 91 (2), 321-328.

Feenstra R., C. Hong, H. Ma, and B. Spencer, 2013, Contractual Versus Non-Contractual Trade: the Role of Institutions in China, Journal of Economic Behavior and Organization, 94, 281-294

Gaulier, G. and S. Zignago, 2010, BACl: International Trade Database at the Productlevel (The 1994-2007 Version), CEPII, WP No.2010-23.

Hale, G., and C. Long. 2011. Are There Productivity Spillovers from Foreign Direct Investment in China?, Pacific Economic Review, 16 (2), 135-53.

Harding, T. and B. S. Javorcik, 2011, Roll Out the Red Carpet and They Will Come: Investment Promotion and FDI Inflows, Economic Journal, 121 (557), 1445-76.

Harding, T., Javorcik, B.S., 2012, Foreign direct investment and export upgrading, The Review of Economics and Statistics 94 (4), 964-80.

Hausmann, R. and B. Klinger, 2007, The Structure of the Product Space and the Evolution of Comparative Advantage, CID Working Paper No.146, Harvard University.

Hausmann, R., and C. Hidalgo, 2011, The Network Structure of Economic Output, Journal of Economic Growth, 16 (4), 309-42.

Head, K., and T. Mayer, 2014, Gravity Equations: Workhorse,Toolkit, and Cookbook, chapter 3 in Gopinath, G, E. Helpman and K. Rogoff (eds), vol. 4 of the Handbook of International Economics, Elsevier: 131-195.

Helpman, E., Melitz, M., and Y. Rubinstein, 2008, Estimating Trade Flows: Trading Partners and Trading Volumes, Quarterly Journal of Economics 123 (2), 441-487. 
Hidalgo, C. A., B. Klinger, A.-L. Barabási, and R. Hausmann, 2007, The Product Space Conditions the Development of Nations, Science, 317, 482-487.

Kali, R., J. Reyes, J. McGee, and S. Shirrell, 2013, Growth Networks, Journal of Development Economics, 101, 216-27.

Li X. and A. A. Liu, 2014, Imitating to Export, Cheung Kong Graduate School of Business, mimeo.

Lin J. Y., 2011, New structural economics: a framework for rethinking development, the World Bank, Washington DC.

Mayneris F. and S. Poncet, 2015, Entry on difficult export markets by Chinese domestic firms: The role of foreign export spillover, World Bank Economic Review, 29 (1), 150-179.

Poncet, S. and F. Starosta de Waldemar, 2015, Product Relatedness and Firm Exports in China, World Bank Economic Review, forthcoming.

Santos Silva, J. M. C. and S. Tenreyro, 2006, The Log of Gravity, The Review of Economics and Statistics, 88 (4), 641-658.

Santos Silva, J. M. C. and S. Tenreyro, 2011, Further Simulation Evidence on the Performance of the Poisson Pseudo-Maximum Likelihood Estimator, Economics Letters, $112(2), 220-222$.

Schminke, A. and J. Van Biesebroeck, 2013, Using Export Market Performance to Evaluate Regional Preferential Policies in China, Review of World Economics, 149 (2), 343-367.

Upward, R., Z. Wang and J. Zheng, 2013, Weighing China's export basket: the domestic content and technology intensity of Chinese exports, Journal of Comparative 
Economics, 41 (2), 527-543.

Wang, J., 2013, The Economic Impact of Special Economic Zones: Evidence From Chinese Municipalities, Journal of Development Economics, 101, 133-147.

Wang, Z., and S.-J. Wei. 2010, What Accounts for the Rising Sophistication of China's Exports? In R. Feenstra and S.-J.Wei, Eds., China's Growing Role in World Trade, 63-104. Chicago: University of Chicago Press.

Wilcoxon, F., 1945, Individual comparisons by ranking methods, Biometrics, 1, 80-83. 
Figure A-1 - Map of EPZs

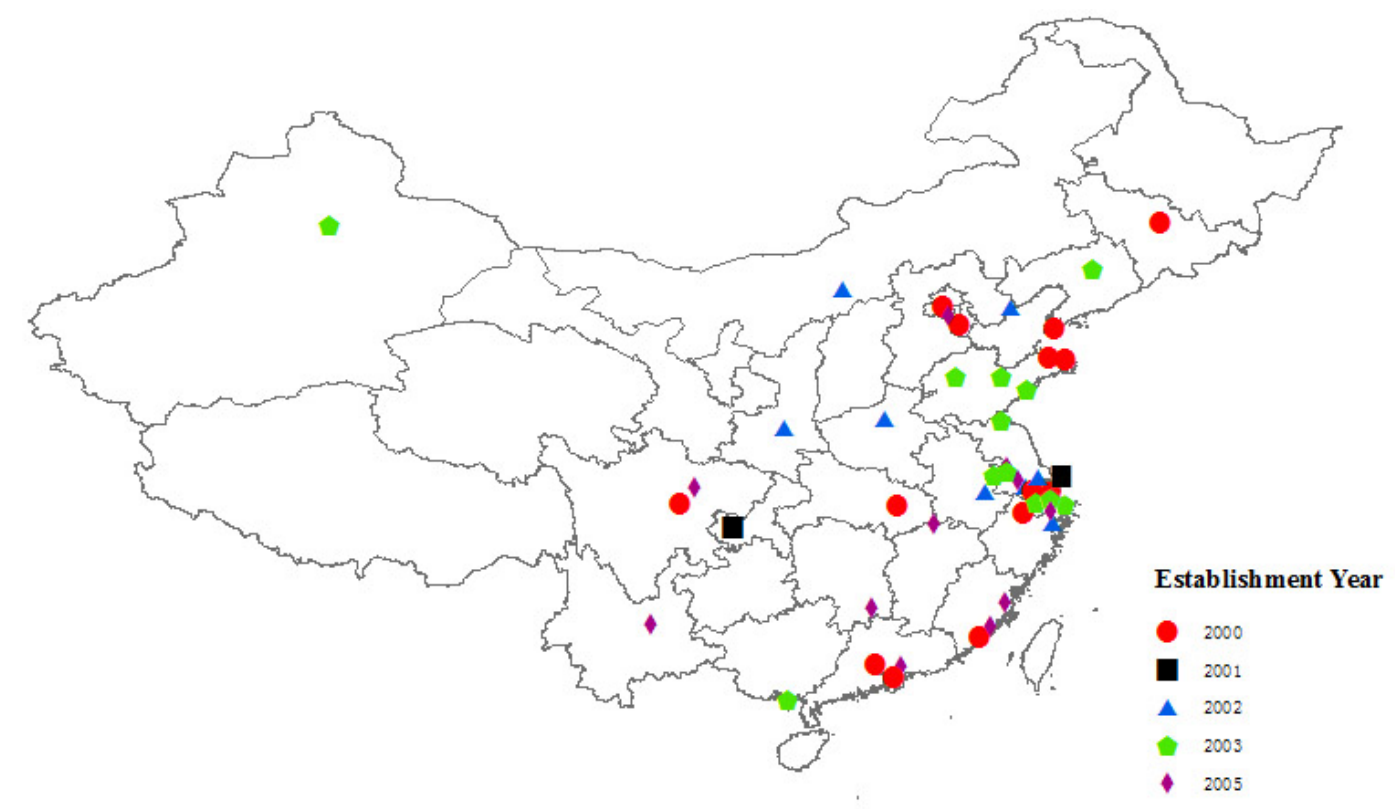

Table A-1 - Summary statistics

\begin{tabular}{||l|cccc||}
\hline \hline Variable & Mean & within city Std. Dev. & Min & Max \\
\hline Exports $\left.\right|_{k t}$ (million Yuan) & 203.8 & 2228,7 & 0 & 290,640 \\
Total sales $\left.\right|_{k t}$ (million Yuan) & 998.8 & 5,860 & 0 & 638,121 \\
EPZ dummy (1 after establishment, otherwise 0) & 0.45 & 0.50 & 0 & 1 \\
Sector target dummy & 0.45 & 0.50 & 0 & 1 \\
\hline \hline
\end{tabular}

Statistics are calculated for the sample used in the regressions, which includes 72,048 observations between 1998 and 2007. Exports $/ k t$ refers to the exports of locality $/$ in sector $k$ for year $t$. 
Figure A-2 - Histogram of bilateral relatedness $(158 \times 158$ sectors $)$

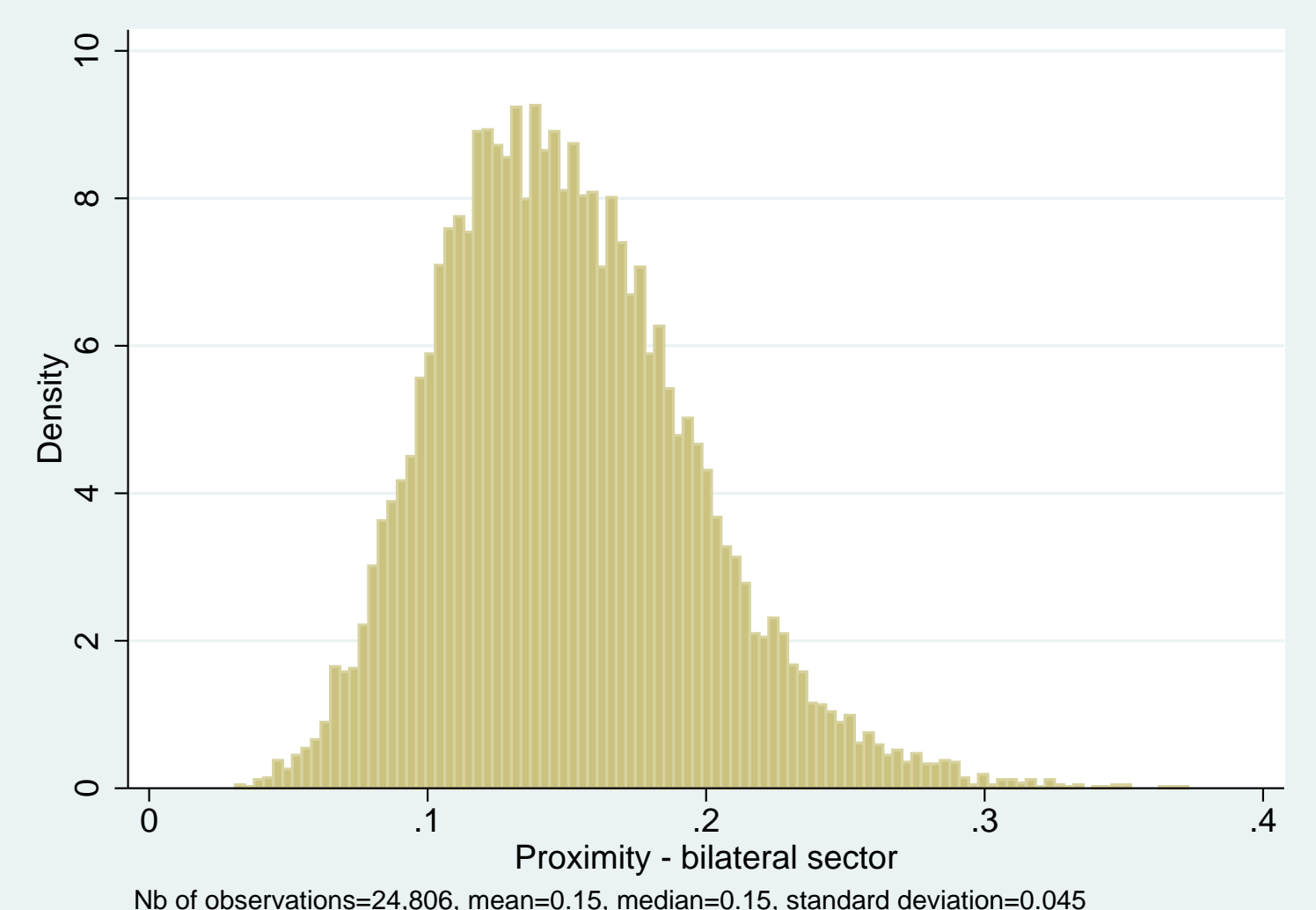

$\mathrm{Nb}$ of observations $=24,806$, mean $=0.15$, median $=0.15$, standard deviation $=0.045$ 
Figure A-3 - Distribution of density (city-sector): targeted versus non-targeted sectors (47 cities, 158 sectors)

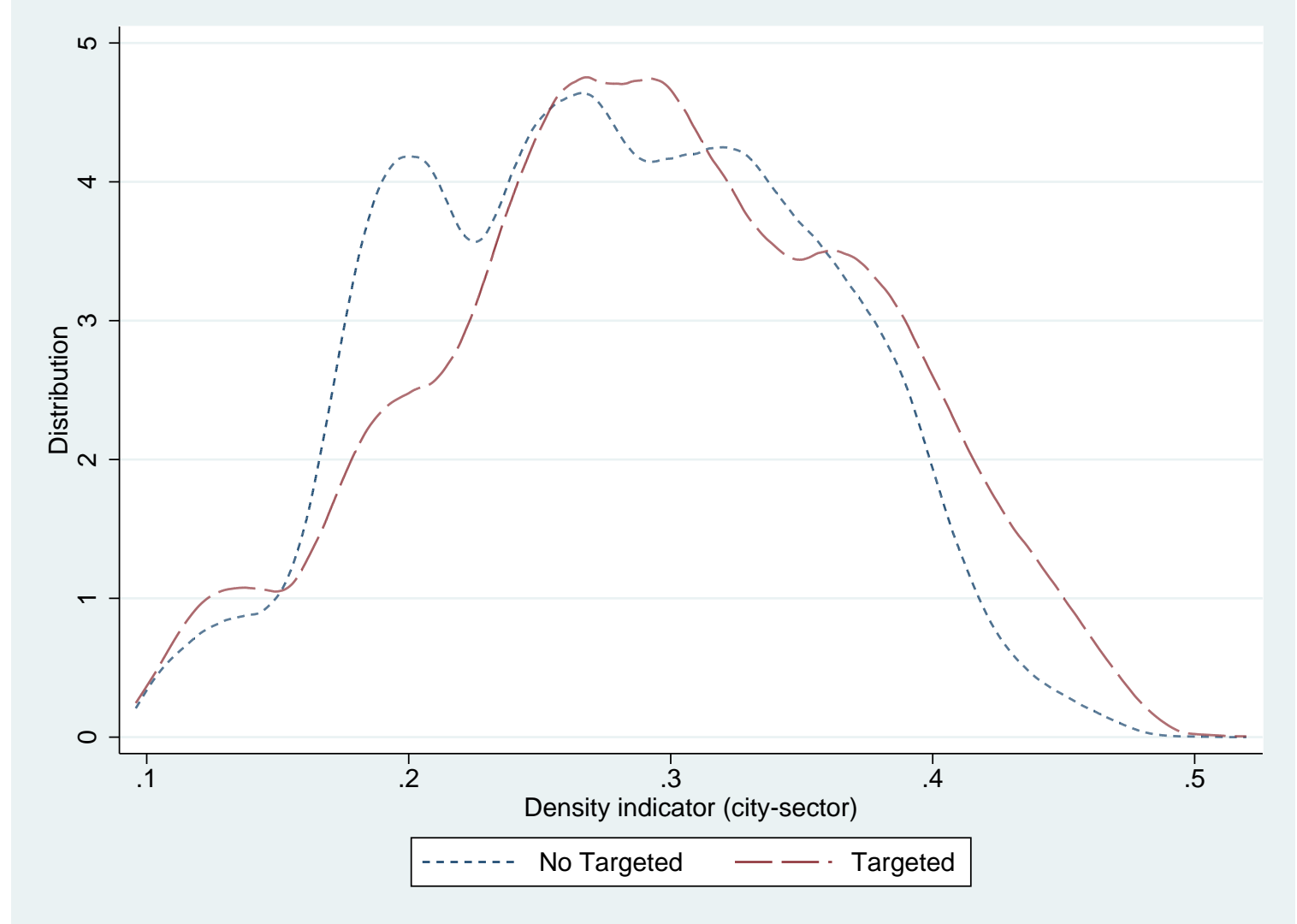

Note: See the text in Section 3.3 for the exact definition of the density index. 
Figure A-4 - Within-city distribution of density (city-sector)

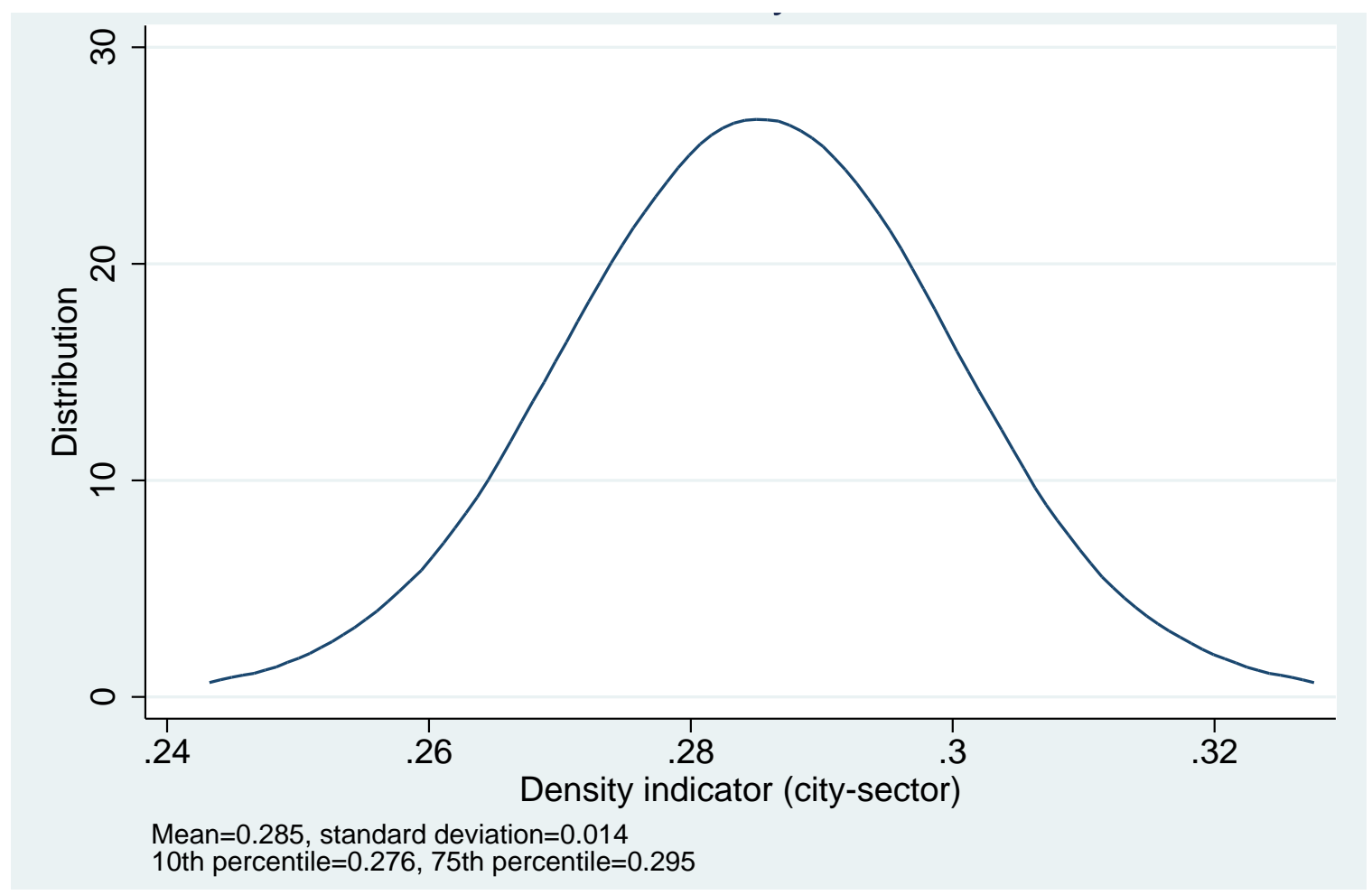

Note: The figure displays the average within city percentiles of density. Percentiles of the city-sector density index are computed for each city and then average over all cities. 
Table A-2 - List of EPZs

\begin{tabular}{|c|c|c|c|}
\hline EPZ & Year & EPZ name & Targeted sectors \\
\hline 110113 & 2000 & Beijing Tianzhu & $\begin{array}{l}\text { Industrial automation equipment; Electronic information products; } \\
\text { Biological medicine }\end{array}$ \\
\hline 120107 & 2000 & Tianjin & Electronic information products; Communication equipment \\
\hline 1303 & 2002 & Hebei Qinhuangdao & $\begin{array}{l}\text { Grain, oil and food processing industry; Automobile and accessories; } \\
\text { The equipment manufacturing industry; New building materials }\end{array}$ \\
\hline 1310 & 2005 & Hebei Langfang & $\begin{array}{l}\text { Electronic information products; Opto-mechatronics; Precision ma- } \\
\text { chinery }\end{array}$ \\
\hline 1501 & 2002 & Huhehaote & $\begin{array}{l}\text { Electronic information products; Biological medicine; Light indus- } \\
\text { trial and textile products; New material industry; Food; Light indus- } \\
\text { trial machinery }\end{array}$ \\
\hline 2101 & 2003 & Shenyang & $\begin{array}{l}\text { Electronic information products; Biological medicine; The equip- } \\
\text { ment manufacturing industry; New material industry }\end{array}$ \\
\hline 2102 & 2000 & Liaoning Dalian & $\begin{array}{l}\text { Electronic information products; Mechanics; Plastics; Household } \\
\text { appliances }\end{array}$ \\
\hline 2202 & 2000 & Jilin Hunchun & Wood processing; Model based material processing; Clothing \\
\hline 310114 & 2005 & Shanghai Jiading & $\begin{array}{l}\text { Electronic information products; Automobile and accessories; Pre- } \\
\text { cision machinery; New material industry; Photoelectronics }\end{array}$ \\
\hline 310115 & 2001 & Jinqiao & $\begin{array}{l}\text { Electronic information products; Opto-mechatronics; Precision ma- } \\
\text { chinery; Fine chemical industry }\end{array}$ \\
\hline 310117 & 2000 & $\begin{array}{l}\text { Shanghai Songjiang } \\
\text { and B Zone }\end{array}$ & $\begin{array}{l}\text { Biological medicine; New material industry; Food; Light industrial } \\
\text { machinery; Fine chemical industry }\end{array}$ \\
\hline 310118 & 2003 & Shanghai Qingpu & $\begin{array}{l}\text { Electronic information products; Automobile and accessories; The } \\
\text { equipment manufacturing industry; Precision machinery; New ma- } \\
\text { terial industry }\end{array}$ \\
\hline 310120 & 2003 & Shanghai Minhang & $\begin{array}{l}\text { Electronic information products; Opto-mechatronics; Precision ma- } \\
\text { chinery; Mechanics }\end{array}$ \\
\hline 3201 & 2003 & $\begin{array}{l}\text { Jiangsu Nanjing and } \\
\text { South Zone }\end{array}$ & Electronic information products; Automobile and accessories; Food \\
\hline 3202 & 2002 & Jiangsu Wuxi & $\begin{array}{l}\text { Electronic information products; Opto-mechatronics; Precision ma- } \\
\text { chinery; New material industry }\end{array}$ \\
\hline 3204 & 2005 & Jiangsu Changzhou & $\begin{array}{l}\text { Electronic information products; New material industry; Mechan- } \\
\text { otronics }\end{array}$ \\
\hline 3205 & 2000 & $\begin{array}{l}\text { Jiangsu Suzhou Indus- } \\
\text { trial Park and B Zone }\end{array}$ & $\begin{array}{l}\text { Electronic information products; Automobile and accessories; Pre- } \\
\text { cision machinery; New material industry; Mechanics; Electronic and } \\
\text { electrical appliance; Office machinery }\end{array}$ \\
\hline 3206 & 2002 & Jiangsu Nantong & $\begin{array}{l}\text { Electronic information products; Biological medicine; Precision ma- } \\
\text { chinery; Clothing }\end{array}$ \\
\hline 3207 & 2003 & Jiangsu Lianyungang & Electronic information products; Food; Mechanics; Furniture \\
\hline 3210 & 2005 & Jiangsu Yangzhou & $\begin{array}{l}\text { Electronic information products; Light industrial and textile prod- } \\
\text { ucts; Energy-saving materials; Environmental protection machinery }\end{array}$ \\
\hline 3211 & 2003 & Jiangsu Zhenjiang & $\begin{array}{l}\text { Electronic information products; Automobile and accessories; Opto- } \\
\text { mechatronics; Precision machinery; Photoelectronics }\end{array}$ \\
\hline
\end{tabular}


Table A-3 - List of EPZs, continued

\begin{tabular}{|c|c|c|c|}
\hline EPZ & Year & EPZ name & Targeted sectors \\
\hline 3301 & 2000 & Zhejiang Hangzhou & $\begin{array}{l}\text { Electronic information products; Household appliances; Communi- } \\
\text { cation products }\end{array}$ \\
\hline 3302 & 2002 & Zhejiang Ningbo & $\begin{array}{l}\text { Precision machinery; Light industrial and textile products; Informa- } \\
\text { tion home appliance; Integrated circuits }\end{array}$ \\
\hline 3304 & 2003 & Zhejiang Jiaxing & Electronic information products; Mechanics; Precision instruments \\
\hline 3402 & 2002 & Anhui Wuhu & New material industry; Electronic and electrical appliances \\
\hline 3501 & 2005 & Fujian Fuqing & $\begin{array}{l}\text { Electronic information products; The equipment manufacturing in- } \\
\text { dustry; Precision machinery; Light industrial and textile products; } \\
\text { Food; New energy; Fine chemical industry; Consumer electronics; } \\
\text { Equipment manufacturing; Instruments and Apparatus }\end{array}$ \\
\hline 3502 & 2000 & Fujian Xiamen & $\begin{array}{l}\text { Electronic information products; Biological medicine; Precision ma- } \\
\text { chinery }\end{array}$ \\
\hline 3505 & 2005 & Fujian Quanzhou & $\begin{array}{l}\text { Electronic information products; Biological medicine; New material } \\
\text { industry; Aviation industry; Aircraft parts manufacturing and repair- } \\
\text { ing }\end{array}$ \\
\hline 3604 & 2005 & Jiangxi Jiujiang & $\begin{array}{l}\text { Electronic information products; New material industry; Food; New } \\
\text { energy; Beverages }\end{array}$ \\
\hline 3701 & 2003 & Jinan & Electronic information products; Precision machinery \\
\hline 3702 & 2003 & Shandong Qingdao & $\begin{array}{l}\text { Electronic information products; Precision machinery; New material } \\
\text { industry; Fine chemical industry }\end{array}$ \\
\hline 3706 & 2000 & $\begin{array}{l}\text { Shandong Yantai and B } \\
\text { Zone }\end{array}$ & $\begin{array}{l}\text { Electronic information products; New material industry; Mechanics; } \\
\text { Fine chemical industry; Bioengineering; Medicine }\end{array}$ \\
\hline 3707 & 2003 & Weifang & Electronic information products; New material industry; New energy \\
\hline 3710 & 2000 & Shandong Weihai & $\begin{array}{l}\text { Electronic information products; Precision machinery; New material } \\
\text { industry; Food; Medicine }\end{array}$ \\
\hline 4101 & 2002 & Henan Zhengzhou & Electronic information products; New material industry; Clothing \\
\hline 4201 & 2000 & Hubei Wuhan & $\begin{array}{l}\text { Electronic information products; Food; Mechanics; Bioengineering; } \\
\text { Beverages; Medicine }\end{array}$ \\
\hline 4310 & 2005 & Hunan Chenzhou & $\begin{array}{l}\text { Electronic information products; Precision machinery; New material } \\
\text { industry; Deep processing of non-ferrous metals }\end{array}$ \\
\hline 4401 & 2000 & Guangdong Guangzhou & $\begin{array}{l}\text { Electronic information products; Biological medicine: Precision ma- } \\
\text { chinery; Household appliances; Photoelectronics; Fine chemical in- } \\
\text { dustry }\end{array}$ \\
\hline 4403 & 2000 & Guangdong Shenzhen & $\begin{array}{l}\text { Electronic information products; The equipment manufacturing in- } \\
\text { dustry }\end{array}$ \\
\hline 4413 & 2005 & Guangdong Huizhou & $\begin{array}{l}\text { Electronic information products; Automobile and accessories; Plas- } \\
\text { tics; Clothing; Textile }\end{array}$ \\
\hline 4505 & 2003 & Guangxi Beihai & $\begin{array}{l}\text { Electronic information products; Biological medicine; New building } \\
\text { materials; Precision machinery; Fine chemical industry }\end{array}$ \\
\hline 5101 & 2000 & $\begin{array}{l}\text { Sichuan Chengdu and } \\
\text { West Zone }\end{array}$ & $\begin{array}{l}\text { Electronic information products; Precision machinery; Photoelec- } \\
\text { tronics; Medicine; Aerospace parts }\end{array}$ \\
\hline 5107 & 2005 & Sichuan Mianyang & $\begin{array}{l}\text { Electronic information products; Biological medicine; New material } \\
\text { industry }\end{array}$ \\
\hline 5301 & 2005 & Yunnan Kunming & $\begin{array}{l}\text { Electronic information products; Biological medicine; New material } \\
\text { industry; Mechanotronics; Diamond, jewelry and jade processing }\end{array}$ \\
\hline 6101 & 2002 & Shaanxi Xi'an & Electronic information products; Precision machinery \\
\hline 6501 & 2003 & Xinjiang Wulumuqi & $\begin{array}{l}\text { Electronic information products; Mechanics; Medicine; Building ma- } \\
\text { terials; Chemical industry }\end{array}$ \\
\hline 500112 & 2001 & Chongqing & $\begin{array}{l}\text { Electronic information products; Biological medicine; Automobile } \\
\text { and accessories; Motorcycles; Fine chemical industry }\end{array}$ \\
\hline
\end{tabular}

